This is a self-archived version of an original article. This version may differ from the original in pagination and typographic details.

Author(s): Kerr, Sari; Maczulskij, Terhi; Maliranta, Mika

Title: Within and between firm trends in job polarization : the roles of globalization and technology

Year: 2020

Version: Accepted version (Final draft)

Copyright: @ T The Author(s) (2019). Published by Oxford University Press. All rights reserved.

Rights: In Copyright

Rights url: http://rightsstatements.org/page/InC/1.0/?language=en

Please cite the original version:

Kerr, S., Maczulskij, T., \& Maliranta, M. (2020). Within and between firm trends in job polarization : the roles of globalization and technology. Journal of Economic Geography, 20(4), 1003-1039. https://doi.org/10.1093/jeg/lbz028 


\title{
Within and Between Firm Trends in Job Polarization: The Roles of Globalization and Technology
}

\begin{abstract}
We analyze occupational polarization within and across firms using a census of matched employeremployee panel data from Finland in the period of 2000-2014. As in most industrialized countries, the Finnish occupational distribution has polarized over the last decades. Using decomposition analysis, we find that jobs involving low-level service tasks increase mostly through the entry dynamics, while the high-level abstract task share increases largely within continuing firms. Worker-level occupational mobility points to some skill upgrading within continuing firms, while labor force entry and retirement contribute the polarizing trend. Instrumental variables (IV) regressions confirm that this occupational restructuring is affected by the globalization of economic activity, including trade in goods and services, offshoring and outsourcing. For example, firms that outsource tasks abroad are more prone to lay off production workers, while domestic outsourcing leads to a reduction of both cognitive and service employees.
\end{abstract}

JEL Codes: J24, J31, O33

Keywords: Job polarization, firm, outsourcing, international trade, R\&D, ICT 


\section{Introduction}

Many labor markets display a polarizing job distribution. The trend is documented in most Western economies and often coincides with the polarization of the income distribution. There are numerous papers analyzing the phenomenon, following the seminal Autor, Levy and Murnane (2003) study, which argued that the skill content of technological change is a key driver of polarization. Most existing work concentrates on estimating the degree of polarization at the aggregate labor market level, while some studies link the labor market polarization to other phenomena, such as the growth of ICT, wage inequality or global trade (e.g., Autor, Katz and Kearney, 2006; Böckerman, Laaksonen and Vainiomäki, 2019; Michaels, Natraj and Van Reenen, 2014). To date, only a handful of studies have specifically examined the role of firms in this process (e.g., Cortes and Salvatori, 2015; Heyman, 2016; Harrigan, Reshef and Toubal, 2016; Böckerman et al., 2019), even though the aggregate trends are generated by individual company production and employment decisions and are reflected in the occupational mobility of employees. As a result, the micro-level dynamics of job polarization remain largely uncovered. The current study directly addresses that gap by bringing the role of firms and employees to the front and center of the polarization debate.

The recent literature has paid attention to the role of firm-level restructuring involving entries, exits and the reallocation of labor. Firm-level restructuring has been found to play an important role in management development (Bloom, Sadun and Van Reenen, 2016), productivity growth (Bartelsman, Haltiwanger and Scarpetta, 2013; Hyytinen and Maliranta, 2013), and wage growth (Kauhanen and Maliranta, 2019). Arguably, firm-level restructuring and the resulting worker mobility can play an important role also in polarization. Understanding the firm-level dynamics also matters when designing policy measures to tackle polarization. High performing firms with good management practices, advanced technologies and high productivity may be the best environment for upgrading the skills of 
workers. Therefore, policies that encourage labor mobility between firms may not only increase the efficiency of matching jobs and workers but may also be effective tools in counteracting polarization. ${ }^{1}$

We contribute to the existing polarization literature in three specific ways. First, we examine in greater detail whether the overall polarization pattern takes place within firms or due to changes in the composition of firms. While some earlier studies have examined the pattern of job polarization within and between firms, a careful analysis on the specific contributions of entry and exit margins has been mostly absent from this literature. ${ }^{2}$ Moreover, we study these patterns using establishment-level data also. This extension is important, as establishment-level analyses capture the occupational restructuring within firms that takes place as some firms simultaneously increase employment in certain production units and decrease it in others (Maksimovic and Phillips, 2002). Establishment-level analysis is also less sensitive to the artificial entry and exit of units and allows for the focus to be on organic employment growth that is not confounded, e.g., by mergers and acquisitions (cf. Olsson and Tåg, 2017).

The second novel contribution of our paper is the causal analysis of firm-level mechanisms such as international trade and outsourcing on polarization patterns during a time period when drastic changes were taking place in the global trading environment for goods and tasks. We access exceptionally rich and representative matched employer-employee data that allow merging firm-level information on trade, technology, innovation, and outsourcing. We quantify the causal effects of firm-level imports, exports, and the firm's decision to outsource on job polarization using unexpected trade shocks as an instrumental variable.

Finally, as our linked employer-employee data cover all Finnish companies and employees in the private sector; we can also evaluate the role of employee-level occupational mobility in the polarization dynamics. This extension allows us to disentangle the extent to which occupational changes within and across firms take place via the promoting, hiring, and firing of employees, versus occupation changes

\footnotetext{
${ }^{1}$ Of course, other actions to tackle the skill mismatch in the labor market may include education programs where the number of available places vary to better reflect changes in the balance of demand and supply.

${ }^{2}$ One exception is Böckerman et al. (2019)
} 
that take place as individuals change jobs. Previous studies on firm-level polarization have not taken full advantage of the employee-level data in understanding the dynamics of occupational change.

As in many previous studies, we find evidence of labor market polarization at the aggregate level during the 2000-2014 period. This stems largely from a within-firm destruction of mid-level routine occupations and a simultaneous increase in the highly skilled abstract jobs within existing firms. The share of routine jobs is also declining in the entry margin, indicating that entering firms have a lower concentration of mid-skilled routine jobs and a higher concentration of low-skilled service jobs relative to existing firms. In other words, more "good jobs" are created within incumbent firms while "bad jobs" are created in newly established firms. ${ }^{3}$ Within continuing firms, those with a growing share of "good jobs" are characterized by greater R\&D investment and an increasing intensity of ICT use. This polarization increases in firms that are outsourcing tasks abroad. This suggests that technology and globalization have eroded many routine jobs within firms. Moreover, an increased international goods trade is positively related to the overall polarization pattern within construction firms but is negatively related to the overall polarization pattern within manufacturing firms. In continuing manufacturing firms, growing exports and imports of goods increase the share of routine manual jobs. The latter increase their use of imported intermediate inputs, improve their productivity, and focus the manual job tasks more towards the production of final goods, some of which are then exported. The import - export occupational restructuring nexus may, however, be spurious as imports and exports are heavily correlated at the firm level. To derive estimates of causal relationships, data on shocks in international trade are used to instrument for the imports and exports of goods, as well as for the outsourcing of business activities. The instrumental variables (IV) regressions reveal a more nuanced relationship between global trade and polarization. In particular, while firms with growing imports display declining

\footnotetext{
${ }^{3}$ See also Davis and Harrigan (2011), who introduced the concept of "good jobs" (those above average wage) and "bad jobs" (those below the average wage) in connection to heterogeneous labor market effects from trade liberalization.
} 
polarization, a more mixed pattern emerges in firms with growing exports once causal mechanisms are dealt with more carefully.

The rest of this paper is organized as follows. Section two discusses the relevant empirical and theoretical literature, outlining the conceptual framework for the polarization analysis. Section three describes the Finnish register and survey data, presenting aggregate level statistics on the employeremployee database. The fourth section discusses our empirical decomposition approach, followed by an analysis of aggregate level patterns and the within- and between-firm decomposition analysis. Section five explains the regression approach, including our instrumental variables, while section six provides the results regarding the drivers of within-firm job polarization. The final section concludes the paper by setting our findings into a larger context, and several extensions to the current paper are suggested.

\section{Previous Literature and Conceptual Framework}

Labor market polarization has been the subject of numerous studies over the last two decades. The most cited studies include Autor et al. (2003), Goos and Manning (2007), Goos, Manning and Salomons (2009), and Autor et al. (2006). A comprehensive literature survey is beyond the scope of the current study, but some of the most relevant papers are discussed in Acemoglu and Autor (2011) and Oesch and Rodriguez Menes (2010). Indeed, most studies have examined job polarization within countries and industries, while firms are mostly absent from this literature. ${ }^{4}$ Specifically, our key contribution is a careful analysis of firm-level polarization patterns, with a focus on the extensive versus intensive margin of polarization, along with analyses of occupational mobility by individual workers. This area is not well covered by the previous literature surveys. Hence, we focus below on the selected set of studies that are particularly relevant for the setting of the current study.

\footnotetext{
${ }^{4}$ One bridge study between the aggregate level and firm-level literatures is Goos, Manning and Salomons (2014), who analyze polarization at the industry level. They find relatively strong polarization in Finland during the period of 1993-2010, ranking it number 7 among the 16 EU countries analyzed.
} 
More recently, firm-level studies have used French data (Harrigan et al., 2016), Swedish data (Heyman, 2016), and data from the UK (Cortes and Salvatori, 2015). Cortes and Salvatori (2015) use establishment-level data from the UK and find significant specialization across establishments into routine and nonroutine tasks. An increase in the number of establishments specializing in nonroutine cognitive tasks explains much of the job polarization, but the adoption of new technologies is not associated with lower employment growth within a specific establishment. Moreover, changes in the industrial composition largely explain the decline in routine manual occupations and contribute to the increase of cognitive occupations. Heyman (2016) similarly finds that both within- and between-firm components are important in explaining the overall pattern of polarization in Sweden. Harrigan et al. (2016) find that job polarization has occurred, but mostly due to changes in the composition of firms. They also look at the contribution of net entry on the firm-level polarization pattern and show that, for example, the decrease in the share of industrial and clerical tasks can be accounted for by the between (continuing) firm component, as well as firm net entry. However, Harrigan et al. (2016) do not examine the separate contributions of entry and exit. This would be highly informative, as the decrease in the share of routine occupations could be explained by either the entry dynamics (new firms are less concentrated in employing routine workers) or by the exit dynamics (firms that initially employed many routine workers have exited the labor markets). Of course, most exiting firms are young, suggesting that entries and exits are closely related in a churn process, which justifies a focus on the net entry (Hyytinen and Maliranta, 2013). However, entries and exits do need not be only flip sides of the same coin as competitive entrants may result in downsizing among incumbents as well as increasing exits. In our paper, we create a more detailed decomposition than previous studies and look at the separate contributions of firm entry and exit on the polarization pattern in Finnish firms using a full census of all firms rather than a survey (see also Böckerman et al., 2019).

There is also a growing interest in the following drivers of polarization: technological change, offshoring and globalization. The theoretical mechanism behind ICT and job polarization suggests that 
ICT capital acts as a substitute for mid-skilled labor, yet it might complement high-skilled labor and have relatively little connection to low-skilled labor. During times of increasing ICT intensity, job polarization ensues. The empirical findings match the theory. Studies examining the links between ICT and occupational restructuring include the paper by Böckerman et al. (2019), who use similar underlying Finnish data to evaluate whether the ubiquitous technology-based explanations are also relevant at the firm level. They find evidence for polarization at the firm level and argue that ICT adoption by firms may be behind some of the observed patterns. Michaels et al. (2014) find that industries with faster ICT growth exhibit greater increases in the demand for skilled professionals and a faster decline in the demand for medium-skilled workers. Harrigan et al. (2018) find strong results for ICT, R\&D, exporting and importing as drivers of productivity and how they cause a bias towards skilled employment. ${ }^{5}$ Unlike earlier studies, we simultaneously link all of the information on goods and services trade, offshoring, ICT, and R\&D into the census of all firms to enable a comprehensive analysis of the relative impacts of these factors on job polarization.

Recently, a handful of studies have examined international trade as an explanation for employment polarization. ${ }^{6}$ Michaels et al. (2014) find that the explanations based on trade openness are not robust to controlling for related factors, such as R\&D intensity. Van Reenen (2011) argues that international trade does have a role in the polarization of the labor market but acts via technological change rather than acting directly. Harrigan et al. (2016) find that international trade and "technology" are connected in explaining job polarization in French firms. Maliranta (2013) uses a micro-level decomposition of occupational employment changes from the FLEED firm-level and argues that global firms are

\footnotetext{
${ }^{5}$ Other studies using firm or plant level data to evaluate the causal effect of ICT on productivity and wages include Bartel, Ichniowski and Shaw (2007), Akerman, Gaarder and Mogstad (2015), and Gaggl and Wright (2017). These studies, respectively, are specific to valve manufacturing in five U.S. plants, small businesses in the UK, and broadband adoption in Norwegian firms. Similar natural experiments are not present in Finland during the time period under study.

${ }^{6}$ Keller and Utar (2016) focus on international trade. See also Autor (2010) for a discussion on the role of trade-based explanations and offshoring
} 
significantly contributing to the polarization of jobs in Finland. ${ }^{7}$ Keller and Utar (2016) and Utar (2018) use similar data from Denmark, showing that a large proportion of the mid-wage employment decline can be accounted for by import competition from China. Interestingly, the mid-skilled individuals who lose their jobs can move either up or down in the job hierarchy, depending on their specific skill set. Our contribution to the trade-related literature stems from the causal analysis of the trade of both goods and services, as well as task offshoring, during a time period when significant movements were taking place in the international trade arena and when task offshoring exhibited enormous growth.

To derive causal estimates, recent studies use Scandinavian employer-employee data and exploit firm specific trade patterns together with country specific trade patterns in very detailed product categories (Hummels et al., 2014; Nilsson Hakkala and Huttunen, 2014). These studies focus on the wage and employment effects of offshoring, but a similar instrumental variables (IV) strategy can be exploited in the current study. ${ }^{8}$ Hummels et al. (2014) find that offshoring significantly reduces the firm's domestic employment, mainly among low-skilled employees. Among staying employees, wages decline for the low-skilled but increased for the high-skilled workers. Nilsson Hakkala and Huttunen (2014) find that firm-level offshoring has a positive impact on overall employment, especially among production workers. Interestingly, this result has been rationalized by Grossman and Rossi-Hansberg (2008) and, more recently, by Baldwin and Robert-Nicoud (2014), who show that the increased trading of tasks and services can boost the domestic demand for low-skilled workers, leading to increased employment and wages also for the groups whose tasks are being offshored. ${ }^{9}$ The construction of instrumental variables is discussed in detail in section 4 below.

\footnotetext{
${ }^{7}$ Loosely related, Böckerman and Maliranta (2013) use Finnish employer-employee data to determine if the offshoring activity by firms relates to worker well-being. They find some "polarization" in job satisfaction as a result of offshoring. See also Crinó (2010).

${ }^{8}$ The key assumption is that worldwide shocks in the export supply and import demand are exogenous to firms in small countries (e.g., Denmark and Finland), and that they vary by partner country and product.

${ }^{9}$ This is due to a productivity effect that takes place when the cost of offshoring falls in an environment where some offshoring is already taking place to begin with.
} 
To summarize, we specifically contribute to the existing literature by examining firm-level direct evidence for the hypothesis that forces related to technological progress and globalization are behind the polarization of jobs. We have exceptionally rich employer-employee data covering the entire private sector during a particularly interesting era, where we can link information on the trade in goods and services and large-scale firm-level surveys on ICT usage, R\&D, and outsourcing. We consider arguably exogenous instruments to deal with the endogeneity of firm-level exports and the offshoring of jobs, which the previous polarization research has not done. Finally, to complement the decomposition analysis performed at the firm-level, we exploit the fact that individual workers can be tracked over time within and across firms. Unlike earlier firm-level studies, we explain how worker-level occupational mobility contributes to the observed polarization patterns.

\section{Data and Statistics}

\subsection{Finnish Employer-Employee Data}

We make extensive use of the Finnish Longitudinal Employer-Employee Data (FLEED), which is created for research purposes by Statistics Finland and is based on various administrative registers that are linked together using unique identification codes for persons, companies and plants. The registers combined to form FLEED include employment and wage statistics, educational registers, taxation records, the business register, and financial statement statistics. FLEED covers the entire labor force of Finnish private enterprises subject to the value-added tax (VAT), making it a representative data source for the national economy for the period of 1995-2014.

The information on the occupations of individuals, a key variable for our paper, originates from the employment register. The occupations for the years 2000-2009 are based on the ISCO-88 classification, while a new classification was introduced in 2010 (ISCO-08). We use a crosswalk code constructed by Statistics Finland to recode the occupations in 2000-2009 to match the new classification. 
The different occupation classifications are thus harmonized across time and are suitable for a long-term analysis for our study period of 2000-2014.

Many earlier studies have used occupational tasks to group the occupations into more versus less skill-intensive occupations. Specifically, the ISCO occupations are first classified into the following three main task groups following Acemoglu and Autor (2011): 1) nonroutine cognitive (abstract), 2) routine, and 3) nonroutine manual (service) tasks. The abstract group mostly includes managers, professionals and technical workers; the routine group includes sales, clerical, production and operator work; and services include cleaning, elementary work, personal care and services (cf. Böckerman et al., 2019). ${ }^{10}$ We have further manually distinguished between routine manual and routine cognitive tasks (e.g., Autor et al. 2003). Routine occupations that involve analytic and interactive tasks are defined as routine cognitive occupations (such as clerical work). Another group involves picking, sorting or repetitive assembling tasks, and these are included in the group of routine manual occupations (such as craft workers and plant and machine operators).

Identifying and measuring the task groups appropriately is challenging for two reasons. First, the occupation classifications were revised during the 2000-2014 period, so mapping ISCO-88 with ISCO08 may affect the results even when using the crosswalk constructed by Statistics Finland. To this end, we have examined how well the mapping works by plotting the employment figures across 1-digit occupation groups over the $2000-2014$ period. ${ }^{11}$ Figure A1 shows no notable dips or jumps in the number of employees between 2009 and 2010 when the classification changes. Second, the tasks within a specific occupation may have changed over the 15-year inspection period. We evaluate the robustness of the main results presented in this paper by using alternative occupation categories that are not based on such task measures. We discuss these robustness analyses below.

\footnotetext{
${ }^{10}$ We thank Jari Vainiomäki for the codes to convert the Finnish ISCO 2010 classification into groups based on routine content.

${ }^{11}$ Farmers and those working in military service are excluded throughout the following analyses.
} 
A description of the worker characteristics by occupation group is shown in Table 1. To this sample we include firms that have at least 10 employees and drop employees who worked for the firm for less than 6 months during the observation period. ${ }^{12}$ The relative skill ranking of the task-based groups has remained unchanged, although the share of workers with a college degree and the average years of education have increased in every occupation group. There is considerable gender segregation across occupations, albeit decreasing over time. All occupations, except routine cognitive, seem to be aging, and workers doing abstract tasks have the highest average age among occupations. There are large differences in the average annual earnings across occupations. The relative wage increases are the smallest in those routine cognitive occupations whose share of total employment has been declining over time.

Descriptive statistics for the FLEED data are shown in Table 2 by firm type. In total, the data includes approximately 17 thousand firms, of which 6 thousand are continuing firms, 6 thousand are newly established firms, and 5 thousand are exiting firms. The total number of employees is approximately 500 thousand in continuing firms in 2000 and is slightly more in 2014 . The share of females is the highest in new firms (45\%) compared to older or exiting firms (40-43\%), and the average annual earnings are higher in older firms compared to younger firms (41 thousand versus 38 thousand euro in 2014). Evident in the data is a relatively rapid skill upgrading among the employed Finnish labor force (2000 vs. 2014), partly caused by the aging out of the labor force by the less educated baby-boomer generation. The most prevalent group in 2014 was the "abstract occupations" group, while in 2000, the "routine manual tasks" group was the largest group, especially among exiting firms. The share of service workers is highest among newly established firms compared to other firm types (19\% versus $12 \%$ in 2014).

${ }^{12}$ This restriction ensures that the firm is the main employer of the employee, and we are able eliminate the numerous seasonal and other temporary workers whose movements may not be representative of any polarization trend. 
The auxiliary data sources combined into FLEED include the Finnish customs export and import data for goods and services, the survey on the offshoring of business activities collected by Statistics Finland, as well as the ICT and R\&D surveys. In the main empirical analyses, we examine the (causal) effects of offshoring and the exporting and importing of goods on occupational restructuring. In additional tests, we also examine how exporting and importing of services, as well as ICT and R\&D are related to changes in occupation shares within firms. Each of these data sources is described below, and the data sets are summarized in section 3.7.

[Tables 1-2 in here]

\subsection{The Finnish Customs Data}

The Finnish Customs data cover both the exports and imports of goods at the firm level for the period of 1999-2014 and include the total values of imports and exports to/from all partner countries, as well as the imports and exports to/from EU countries. By request, we obtained the euro values of trade at the most detailed goods category level (8-digit level). Statistics Finland has also calculated, for each firm, the number of $\mathrm{CN}$ (Combined Nomenclature) categories ${ }^{13}$ and the number of countries the firm imports to and exports from. According to the OECD's recommendation, the euro values are "free on board" (FOB) for exports, and "cost, insurance and freight" (CIF) for imports. Before 2009, the total value of the firm's international trade had to exceed 1,000 euros to be included in the customs data. After 2009, firms with even very small international trade values are also included.

\subsection{Data on service exports and imports}

The service export and import data span the period of 2002-2014 and are based on a survey that covers the census of all large companies (at least 100 employees), as well as all firms that had in the previous year reported that they we engaged in international services trade, were owned by a foreign entity, or

\footnotetext{
${ }^{13}$ The Combined Nomenclature is the common nomenclature of the European Community. The 8-digit sub-headings in the nomenclature are used in export declarations and in statistical declarations on international trade.
} 
owned affiliates in a foreign entity. The data also include a $16 \%$ random sample of medium-sized firms (20-100 employees) and 10\% random sample of small firms (less than 20 employees). The largest categories of services exported include data processing services and international intracorporate services (including overheads paid by international subsidiaries related to HR- and ICT-services), while Finnish firms mostly import data processing services and services in the category of "other business functions" (e.g., translation and security) (see Haller et al., 2014).

\subsection{International sourcing survey}

The international sourcing survey is an important globalization-related source of data revealing whether a firm has moved some of its business functions abroad (i.e., offshored jobs during a given period). The survey also includes questions on whether a firm has outsourced some of its business functions domestically, or whether it is planning to increase international sourcing or remain at the same level of offshoring as in the previous 5-year period. This information pertains to the years 2001-2006. The international sourcing survey is a census of those firms that employ more than 100 persons and a random sample of smaller firms (with a response rate of $83 \%$ ). ${ }^{14}$

\subsection{ICT survey}

The ICT surveys are available in a uniform format for 2000-2014 and describe the adoption and use of ICT by Finnish private companies, as well as their practices related to e-commerce. The sample includes the universe of large firms (more than 100 employees) and a separate random sample of smaller firms (5-99 employees) each year. The sampling frame excludes arts and entertainment, veterinary activities, financial and insurance activities, agriculture, forestry and fishing, and all public sector service activities. Each year, approximately 3,000 firms answer the survey with the response rate varying between $72 \%$ and 74\%. During the observation period, practically all companies surveyed had adopted some basic ICT

\footnotetext{
${ }^{14}$ The survey was simultaneously completed in all Nordic countries and the Netherlands. For more details, including the survey instrument, see Statistics Denmark et al., 2008.
} 
tools, but the share of workers using the tools varied from company to company and, on average, increased from less than 60 percent (in 2001) to nearly 80 percent (in 2014). More information on the ICT survey can be found in Böckerman et al. (2019).

\section{6. $R \& D$ survey}

The R\&D surveys are available at the firm level in a uniform format for the period of 1998-2014. The statistics are based on data obtained from enterprises, universities, central university hospitals, polytechnics and public sector organizations. The R\&D surveys are targeted to the firms that are most likely to conduct R\&D. Each year, the survey covers all firms that had previously reported R\&D activity, all large firms (more than 100 employees), all firms that received public R\&D subsidies or applied for an R\&D tax break, and a random sample of medium sized firms (10-100 employees). ${ }^{15}$ The sample size totals approximately 4,000 firms per year, with the response rate varying between $75 \%$ and $78 \%$. The survey questions cover in detail each firm's R\&D activities and expenditures.

\subsection{Description of the Firm Sample Across Data Sets}

Table 3 reports the descriptive statistics and coverage analyses for the sample of continuing firms included in the main regressions. Below, we characterize the final firm sample and the various data sets that are combined into the total FLEED. For the estimation, we include firms that had at least 10 employees in both focal years and exclude employees who had zero earnings and those who worked less than six months during the observation year. ${ }^{16}$

As the FLEED covers all private sector employees and firms, it includes a large number of observations both at the worker and firm level. The customs data on the trade of goods is a census of importing and exporting firms, and the absence of a firm from those data simply indicates that the firm

\footnotetext{
${ }^{15}$ Small firms (less than 10 employees) are only included to the extent they received R\&D subsidies. For more information, see http://www.stat.fi/til/tkke/meta_en.html.

${ }^{16} \mathrm{We}$ also report the descriptive statistics for the samples regarding continuing, entering and exiting firms in Table A1 of Appendix.
} 
is not engaged in international trade (i.e., the value of the goods imported and exported by those firms is zero). Of the 6,314 firms that are observed in the business register with an entry date before 2000 and either no exit date or an exit date later than 2014, a total of 2,280 (36\%) report a positive amount of imported or exported goods in 2000 or 2014. In addition, 1,232 report a positive value of service imports or exports. ${ }^{17}$ Of these 6,314 firms, approximately $25 \%$ are in the manufacturing industry, $10 \%$ are in the construction industry, and $45 \%$ are in some service industry.

The coverage related to the three other sets of auxiliary survey data is more limited, although large firms are generally covered by every survey. Of the initial 6,314 surviving firms, 1,052 are covered by the 2001 ICT survey. During the observation period, practically all companies surveyed had adopted some basic ICT tools, but the share of workers using the tools varied from company to company and, on average, increased from 58\% (in 2001) to nearly 76\% (in 2014). For firms surveyed in both years, the change was 19 percentage points. Of the 6,314 surviving firms, 1,111 firms are covered by the 2000 R\&D survey and 747 are covered by the international sourcing survey. According to the R\&D survey, the overall average R\&D expenditure was approximately 6,000 euros per worker in 2000. Finally, approximately $21 \%$ of the firms covered by the sourcing survey reported that they were already sourcing business functions internationally in 2001-2006. In addition, 7\% of the firms responded that they were either planning to increase their international sourcing after 2007 or remain at the same level of offshoring as in the previous 5-year period. The most typical locations for international outsourcing were the new EU-12 countries. The common tasks that are outsourced domestically include ICT services (28\%), transportation and logistics (19\%), production of goods and services $(15 \%)$, and administrative services (15\%). The typical tasks outsourced abroad include the production of goods and services $(12 \%)$. Large firms outsource more than smaller firms, both internationally and within Finland.

[Table 3 in here]

\footnotetext{
${ }^{17}$ In some sense, the service import and export data can also be considered "a census" because the survey attempts to include all firms with known or suspected service imports or exports. We test for the sensitivity of our findings to the treatment of the service trade data in the regression analysis discussed below.
} 


\section{Aggregate Level Analysis and Decomposition Results}

\subsection{Decomposing Aggregate Changes}

The goal of our study is to decompose the changes in occupational employment shares to components taking place within versus across Finnish firms and to relate these changes to the various firm traits described above. We start with a series of simple analyses of occupational employment share changes and then continue with a decomposition.

Specifically, using a formula proposed by Vainiomäki (1999), we decompose the change of aggregate share of occupation $j, \Delta S_{j}$ (measured by number of persons), into the following four components:

$$
\Delta S_{j}=\sum_{i \in C} \Delta S_{i j}^{C} \bar{W}_{i}^{C}+\sum_{i \in C} \bar{S}_{i j}^{C} \Delta W_{i}^{C}+W^{N}\left(S_{j t}^{N}-S_{j t}^{C}\right)+W^{D}\left(S_{j, t-1}^{C}-S_{j, t-1}^{D}\right),
$$

for $j=1,2,3,4$ occupation groups (abstract, routine cognitive, routine manual, nonroutine manual). Superscript $C$ denotes continuing firms (i.e., firms appearing both in $t$ - 1 and $t$ ), $N$ denotes the entrants (i.e., firms appearing in $\mathrm{t}$ but not in $t-1$ ), and $D$ denotes the exiting firms (i.e., firms that exist in $t-1$ but not in $t$ ). $\Delta S_{i j}^{C}=\frac{L_{i j t}}{L_{i t}}-\frac{L_{i j, t-1}}{L_{i, t-1}}$ is the change of the employment share of occupation $j$ from year $t-1$ to $t$ in continuing firms $i . \bar{W}_{i}^{C}=0.5\left(\frac{L_{i, t-1}}{L_{t-1}}+\frac{L_{i t}}{L_{t}}\right)$ is the average employment share of firms $i$ in years $t$ and $t-1$ among continuing firms, and $\bar{S}_{i j}^{C}=0.5\left(\frac{L_{i j, t-1}}{L_{i, t-1}}+\frac{L_{i j t}}{L_{i t}}\right)$ is the average employment share of occupation $j$ in continuing firms $i$ in years $t$ and $t-1 . \Delta W_{i}^{C}=\frac{L_{j t}}{L_{t}}-\frac{L_{j, t-1}}{L_{t-1}}$ is the change of employment share of firm $i$ from year $t-1$ to $t$ among the continuing firms. $W^{N}=\frac{L_{t}^{N}}{L_{t}}$ is the employment share of new /entering firms (in year $t$ ) and $W^{D}=\frac{L_{t-1}^{D}}{L_{t-1}}$ is the employment share of exiting firms (in year $t-1$ ). $S_{j t}^{N}$ and $S_{j t}^{C}$ are the shares of occupation group $j$ among new firms and continuing firms in year $t$, respectively. $S_{j, t-1}^{C}$ and 
$S_{j, t-1}^{D}$ are the shares of occupation group $j$ among the exiting firms and continuing firms in year $t-1$, respectively.

The first term on the right-hand side of Equation (1) gauges the change in the aggregate employment share of occupation $j$ within (continuing) firms. In other words, it is a weighted average change of the employment shares in the continuing firms, where each firm is weighted by its average employment share in year $t-1$ and $t$. The second term measures the change of the aggregate employment share of occupation $j$ attributable to shifts in employment between continuing firms with varying occupation structures. The sum of the first two components is the aggregate change of the employment share of occupation $j$ among continuing firms. The third component indicates the contribution of entries, which is positive when the employment share of occupation $j$ in new firms is higher than in continuing firms (i.e., $S_{j t}^{N}>S_{j t}^{C}$ ). The fourth component indicates the contribution of exits, which is positive when the employment share of occupation $j$ in exiting firms is lower than that in continuing firms. Note that, according to Equation (1), the net effect of entries and exits on the employment share change of occupation $j$ is the difference of the change among all firms and the change among the continuing firms only. In other words, the net entry is equal to $\Delta S_{j}-\Delta S_{j}^{C}$.

Since the FLEED allows us to identify individual establishments as well as firms, it is interesting to include an accounting component for that also. The establishment-level analyses have two main advantages. First, they capture the occupational restructuring within firms that takes place as some firms simultaneously increase employment in certain production units and decrease employment in others or establish entirely new production units and shut down older ones (Maksimovic and Phillips, 2002). Second, they are less sensitive to the artificial entry and exit of units and allow for a focus on the organic employment growth that is not confounded, e.g., by mergers and acquisitions. This is an important extension, as recent evidence suggests that one key channel through which job polarization happens is through mergers and acquisitions (e.g., Olsson and Tåg, 2017). The decomposition analysis is, thus, also done using FLEED's establishment-level data. 


\subsection{Aggregate evidence regarding job market polarization}

It is useful to first examine the aggregate level trends in job polarization using the descriptive analysis and techniques that are prevalent in the literature. Figure 1 shows the change in the share of jobs from 2000 to 2014 by occupation using the 1-digit ISCO-08 classification. The analysis is performed using all employees (and self-employed people) that have an occupation code in the FLEED, whether they work in the private or the public sector. The increase ( $4 \%$-points) in professional occupations corresponds to approximately 100 thousand jobs, while the change in services and managerial jobs ( $2 \%$-points) translates roughly to 60 and 40 thousand jobs, respectively. The occupations that have lost the most jobs ( 2-3\%-points) are related to industrial and clerical tasks, with these changes jointly corresponding to 140 thousand jobs.

An alternative way to characterize the polarization of job distribution is to rank the occupations based on their initial mean wage (annual earnings in 2000) and then examine the changes in employment shares (in \%-points) across those occupations. Figure 2 shows this at the 2-digit occupational level for all sectors, the private sector, and the public sector. The changes in the "all sectors" occupation shares by the average wage level resembles the U-shaped curve found in many other studies. ${ }^{18}$ Notably, this is all driven by the private sector, as there no evidence of a U-shape in the public sector employment changes.

[Figures $1-2$ in here]

18 The smoothed changes are created using the nonparametric LOWESS-method, i.e., the locally weighted scatterplot smoothing. Mitrunen (2013) performed similar analyses with Finnish data for 1995-2008, with largely similar conclusions. 


\subsection{Decomposition Results}

Table 4, Panel A reports the results of the firm-level decomposition in Equation (1). Here, we classify the 4-digit occupations (and sometimes 3-digit occupations) into four main groups based on the tasks they involve: abstract, routine cognitive, routine manual and services. ${ }^{19}$ The analysis demonstrates how the occupations associated with routine tasks have declined in share, while both the abstract and service occupations have increased. The share of routine manual tasks is declining more than the share of routine cognitive tasks (-5.8\%-points versus $-0.8 \%$-points). The decline in routine manual occupations is driven both by the within and between components (among continuing firms). Entries have had a negative contribution to this decline which implies that entering firms have fewer routine manual jobs than the incumbents, and they therefore contribute to the reshaping the occupational structures in the economy. This is somewhat counteracted by the exit mechanism. Note that the signs of the entry and exit components are opposite in all cases, which shows that entries and exits are mutually related. However, sometimes their absolute values differ considerably, e.g. in the change of the routine cognitive tasks. In particular, the opposite sign is suggestive of some churning of firms and jobs via entry and exit. ${ }^{20}$ The decline in routine cognitive jobs is driven by both the within-firm component and the firm entry component. Overall, the decline in routine occupations within firms could be consistent with the hypothesis that many clerical and production tasks have been replaced by computers or robots as a part of an internal reorganization of firms. The negative between-firm component for routine manual occupations indicates that firms with a large share of these types of jobs (e.g., much of the production work) have lost market share in terms of employment, i.e., experienced weaker employment growth relative to other firms. For abstract occupations, the within-component dominates, while the entry-

\footnotetext{
${ }^{19}$ The decomposition analyses are done using private sector firms if they had at least one employee in 2000 and/or 2014. The firm-level regression analysis uses only those firms that had at least 10 workers during the year of observation. Table A2 recalculates the employment shares by occupation and firm type to determine if the overall pattern is sensitive to the size limitation. The pattern is quite robust to excluding the smallest firms, even though the number of firms is reduced quite dramatically.

20 The opposite signs of entry and exit with similar absolute values is expected when a large number of specific firms (e.g. firms with a high share of service tasks or low productivity firms) typically exit soon after entry.
} 
component is most important in the growth of service occupations. Interestingly, and in some contrast to our findings, Böckerman et al. (2019) used data for 2002-2008 and found that during those years, job polarization took place mostly within continuing firms, with only a modest contribution of firm entryexit dynamics.

The decomposition analysis was also performed using FLEED's establishment-level data (Panel B of Table 4). The results are quite comparable to the above analysis using firm-level data. However, there is one interesting difference; the decrease in routine manual jobs and the increase in service jobs is no longer explained by the between-establishment dynamics. More generally, this difference illustrates the potentially important role of intrafirm restructuring that takes place between the establishments of existing firms, given the dominant share of employment created by multiestablishment firms. ${ }^{21}$ For example, a large share of exiting firms have a low share of routine manual tasks, which can be inferred from the large positive exit component in Panel A. However, following firm exit, many establishments actually survive in the ownership of some other firm, i.e., they are "continuing establishments" and, thus, contribute to the within and between components of the establishment-level decomposition, as documented in Panel B. These establishments may also have a large share of routine manual tasks. It is possible that they expand because they belong to firms that redistribute activities involving many routine manual tasks. In this case, they contribute positively to the between component in the establishmentlevel decomposition for routine tasks, as seen in Panel B. On the other hand, these between-dynamics can be negative at the firm-level if the staying firms outsource activities to other firms.

To understand how individual worker mobility contributes to the observed within- and betweenfirm polarization pattern, we separately look at workers who remain in the same firm through the entire observation period versus those who switch jobs. For those workers, occupational mobility is displayed as transition matrices between 2000 and 2014 (Table 5, Panel A and B). In addition, Table 5 shows the occupational distribution of workers that exited after 2000 (Panel C), as well as the distribution of those

${ }^{21}$ In 2014, approximately $2 / 3$ of the employees in our sample worked in firms with at least two establishments. 
workers that entered by 2014 (Panel D). Interestingly, the workers who stay with the same firm display some upward mobility, although the typical worker does not change occupations between 2000 and 2014 , with 67 to 85 percent of workers remaining in their original occupation category. Workers changing firms display less persistence in the routine cognitive and routine manual categories, while experiencing more mobility both upward and downward. Comparing the occupational distributions of exiting and entering workers, we note relatively little difference in the abstract and routine cognitive occupations, while the entering workers are much more heavily concentrated in service occupations and less concentrated in routine manual occupations than the exiting workers. To summarize, the evidence on worker flows helps to understand some of the firm-level patterns described above. For example, the positive within-firm component for abstract jobs comes from the upward worker mobility of existing workers and workers entering the firms who are moving up in the job distribution.

As a robustness test, we perform the decomposition analysis using the regular 1-digit occupation categories instead of task-based groups. Figure 3 shows the total change in the share of occupation groups, along with the proportion of the total change that can be attributed to the within- and betweenfirm components among the staying firms. Figure 4 shows the entry and exit components. Again, these figures demonstrate that the "right-hand side of polarization" is essentially a within-firm phenomenon, i.e., the share of high-wage occupations has increased within the continuing firms. However, a comparison of the aggregate and within-firm patterns reveals that the "middle part of polarization" can be mostly attributed to changes within firms, with a significant part also related to entries. On the other hand, the between-component has also contributed to the pattern by having a negative effect on the employment change of plant operators. These figures also show that a sizeable part of the increase in the service occupation employment share is attributed to the between-firm component and entries, the latter indicating that the employment share of service occupations is typically higher among new firms than (older) continuing firms. 
It should be noted that the definition of firm entry, firm exit and a continuing firm is done using the Business Register and, therefore, excludes employers that are not considered private firms. This exclusion covers, for example, public sector entities, such as municipalities, towns and other large public sector employers. We acknowledge that the job distribution is rather different in those entities than in private sector firms; however, including public sector jobs is outside the scope of the current study due their exclusion from the firm surveys and customs data utilized below in the regression analyses. For descriptive purposes, Figure 2 above shows the change in the occupational distribution between 2000 and 2014 in the public and the private sector.

To summarize, based on various descriptive analyses and decompositions, and regardless of the approach taken or the characterization of occupation groups, the same conclusion stands, as follows: mid-level jobs are disappearing while top- and bottom-level jobs are growing in Finland. Finally, while job polarization in the U.S. has coincided with wage polarization (e.g., Autor et al., 2006; Acemoglu and Autor, 2011), such wage polarization is not common in other countries. ${ }^{22}$ We present some cursory evidence on the changes in the wage distribution, showing that job polarization and increasing wage inequality do not move in tandem in Finland (Figure A2). Instead, the private sector wages have grown fastest in the high-wage occupations, whereas the low-wage occupations in the public sector have experienced the most wage growth - leaving the overall wage growth in the economy relatively flat. This is likely explained by the very different wage setting institutions (collective bargaining) in Finland compared to the U.S.

[Tables 4 and 5 in here]

[Figures 3-4 in here]

\section{Causal analysis of job polarization: Instrumental variables approach}

\footnotetext{
22 There are some contradicting views on the explanatory power of the job polarization phenomenon as the driver of increasing wage inequality (e.g., Mishel, Shierholz and Schmitt, 2013).
} 
Next, we estimate a model for the occupational share changes using the FLEED data at the firm level, where the dependent variable is the change in the share of occupation group $j$ within firm $i$ from 2000 to 2014. We focus here on the firm-level data, as the auxiliary data are not collected at the establishment level. Likewise, we only focus on continuing firms, since the occupation share change can only be observed for firms that exist both in 2000 and 2014. The estimated equation is of the following general form:

$$
\Delta \mathrm{S}_{\mathrm{ijt}+1, \mathrm{t}}=\alpha+\beta_{1} \mathrm{~F}_{\mathrm{it}}+\beta_{2} \log \left(\mathrm{w}_{\mathrm{ijt}}\right)+\beta_{3} \mathrm{age}_{\mathrm{it}}+\beta_{4} \mathrm{I}_{\mathrm{it}}+\varepsilon_{\mathrm{it}},
$$

where $S$ is the employment share, $w$ is the average annual salary of workers in occupation group $j$ in firm $i$ in 2000, age is the average age of employees in the firm in 2000, and $I$ is a vector of nine industry dummies intended to capture any economy-wide shifts that are taking place in the industry. ${ }^{23} F$ denotes the various firm-level traits of interest. In the main analysis, we focus on the measures related to the export and import of goods, and offshoring / outsourcing. In auxiliary tests, we also examine the role of international trade in services, ICT and R\&D.

We measure export (and import) changes by the difference in the log of total exports (imports) in euros between 2014 and 2000. For outsourcing, the explanatory dummy variable receives the value of one if the firm is outsourcing some of its activities in 2001-2006, and zero otherwise. We estimate equation (2) for each occupation group $j$ separately (abstract, routine cognitive, routine manual, and service). Across the four occupation groups, the sum of the coefficients $\beta_{1}$ equals zero.

One potential identification concern is related to firm-level shocks (e.g., in product or service demand, or firm-level productivity) that might simultaneously impact the firm's trading activities and its occupational employment decisions. Dealing with this requires an instrumental variable that impacts the firm's international activities (in particular exports, imports and outsourcing) but is otherwise

\footnotetext{
23 The industry is based on the Standard Industrial Classification and categorized into to the following nine groups: 1) Agriculture, mining and quarrying, 2) Manufacturing, 3) Electricity, gas and water supply, 4) Construction, 5) Wholesale, retail, hotels and restaurants, 6) Transport, storage and communication, 7) Real estate, research and financial services, 8) Public administration, education and health and social work, and 9) Other personal service activities.
} 
orthogonal to its employment decisions. We adopt the instrumental variables approach utilized in the recent studies by Hummels et al. (2014) and Nilsson Hakkala and Huttunen (2014, 2016). Specifically, we create a firm-product-country level measure of exposure to increased world supply using highly detailed data from the Finnish Customs and the UN Comtrade database. First, Comtrade is a comprehensive register of all export and import flows between country pairs and includes goods classifications up to the most detailed 6-digit HS2002 level. We calculate, for each "goods-reporting country" pair, the total imports from the world market minus the imports from Finland and the total exports to the world market minus the exports to Finland. Second, the Finnish customs data are at the firm-goods classification-partner country level and allow us to characterize the exact imports and exports by firm at the most detailed 8-digit goods category level. ${ }^{24}$ We calculate the share of the specific good-partner country as a percentage of the firm's total imports and exports and use it as a weight to take into account how significant any world import or export shock is to a specific firm. Shocks in the world trading environment (such as the China WTO membership in 2001) have firm-specific effects depending on how much each Finnish firm was engaged in trade within the specific goods category affected.

The instrument for firm-level imports is based on the world export supply measure, $\mathrm{WES}_{\mathrm{ckt}}$, which is country $c$ 's total supply of product $k$ to the world market in year $t$, excluding the supply to Finland. To create the instrument, we weight each firm $i$ 's product $k$ from country $c$ at time $t$ with the share of $c-k$ products in the firm's total material imports in 2000 ( $\left.\mathrm{s}_{\text {ick }}\right)$. We then generate the firm-level measure by aggregating across all products from all countries and weighting each product $c-k$ with its share in the

\footnotetext{
${ }^{24}$ One difference between the Comtrade and Finnish Customs data relates to the country classification. While Comtrade reports trade flows between each individual country pair, the Finnish Customs data only report individual countries to the extent that they are among the major export and import partners of Finland. Outside of those, the countries are aggregated by continent. This is accounted for in the generation of the instrumental variable. The amount of trading that takes place between Finnish companies and non-major trading countries is relatively small, i.e., less than 5 percent of total imports and exports in 2000 .
} 
firm's imports in the first period the firm is observed in the trade data. The time-varying instrument for each firm $i$ in year $t$ is as follows:

$$
\mathrm{IV}_{\mathrm{it}}^{\mathrm{I}}=\sum \mathrm{s}_{\mathrm{ick}} \mathrm{WES}_{\mathrm{ckt}}
$$

We expect the WES-based instrument to have a positive impact on the firm's imports, as an increase in the world export supply should encourage additional importing by Finnish firms within the specific goods category. Following Hummels et al. (2014), we assume that firms have pre-existing trading relationships that make it advantageous to source specific goods and services from specific countries, and, likewise, export specific goods and services to specific countries. To some extent, these trading relationships are predetermined. Over time, external shocks in the international environment impact the extent to which such trading relationships remain advantageous.

Following Hummels et al. (2014), we create a similar instrument based on the world import demand (WID) to be used for the firm-level exports. The instrument is calculated as follows:

$$
\mathrm{IV}_{\mathrm{it}}^{\mathrm{E}_{\mathrm{i}}}=\Sigma_{\mathrm{s}_{\mathrm{ick}}} \mathrm{WID}_{\mathrm{ckt}} \text {, }
$$

where WID $_{\text {ckt }}$ is the world import demand. It is calculated as country c's total purchases of good or service $k$ from the world market (minus any purchases from Finland) at time $t$. In general, WID ckt might increase / decrease because of a demand shock, such as consumers' taste changes or firms' change of their use of the specific product. A change in $\mathrm{WID}_{\text {ckt }}$ might also results from a loss in country $c^{\prime}$ s comparative advantage in product $k$. We expect the WID-based instrument to have a positive impact on the firm's exports, as an increased world import demand should encourage additional exporting by Finnish firms within the specific goods category. Since our regression analysis examines first-differences (i.e., the firm-level change in 2000-2014), we use the 2000-2014 change in the $\operatorname{IV}^{\mathrm{E}_{i t}}$ and $\mathrm{IV}_{\text {it }}^{\mathrm{I}}$ as our actual instrumental variables for the international trade of goods. For the outsourcing / offshoring model that pertains to the firm's activities and plans in the early 2000 s, we obtained information from the Comtrade data for an earlier time period (2000-2005) to better fit the timing related to the decision of 
the firm to begin offshoring. The first stage results for the instruments are reported in the regression tables.

\section{Regression Results}

\subsection{Polarization and international trade in goods}

The OLS and 2SLS regression results for goods trading are reported in Table 6, and the results for outsourcing are reported in Table 7. All models include the following basic controls: firm average wage level by occupation, firm average employee age, and industry dummies. The number of employees in 2000 is used as a weight to make the results more reflective of the Finnish private sector labor market. Before commencing with the regression analysis, it is worth noting that job polarization is taking place also within the continuing firms, i.e., the sample used in the regressions (see the "within" and "between" component in Table A2). We have further reported the decompositions for the various survey samples in Appendix Table A3. These results show that the overall polarization pattern within continuing firms is reasonably robust using the smaller samples of firms covered by the trade of goods and services data, as well as the R\&D, outsourcing and ICT surveys.

We first focus on the international trade in goods. In Panel A of Table 6, the OLS regressions are estimated by occupation group and both the trade in goods variables are included simultaneously. The 2SLS regressions for the goods imports and exports are reported in Panel B. In the OLS, firms that increase exports of goods are more likely to increase their share of routine manual jobs, and these same firms are more likely to reduce their share of occupations that involve more cognitive tasks (abstract and routine cognitive) -, i.e., focus more on production activities. The point estimate indicates that a doubling of the euro value of exports is related to an increase in the share of routine tasks by 1.2 percentage points. Similarly, firms that increase their goods imports are also more likely to reduce their share of abstract occupations and increase their share of routine manual occupations. We think that this is driven by a 
spurious connection, i.e., the firms that import intermediate goods and materials are the same ones that tend to export final goods. However, no causal interpretation should be placed on these estimates.

The 2SLS regression results are presented in Panel B. The instruments perform well, with the Cragg-Donald Wald F-test value for the two endogenous variables at 56. The signs of the instruments show that the increased global import demand is positively correlated with Finnish exports, and the increased global export supply is positively correlated with Finnish imports, as expected. The 2SLS results demonstrate why it is necessary to use instrumental variables to break the spurious connection between imports and exports at the firm level. 2SLS verifies the conclusion that abstract jobs are declining in firms that increase their goods exports and imports (i.e., doubling the value of imports or exports leads to a reduction of abstract jobs by $0.5-1$ percentage points), although the effect of imports is no longer statistically significant. Firms with growing imports increase their share of routine manual workers (by 3 percentage points). However, the effect of exports on the change in the employment share of routine manual workers is now negative, while the routine cognitive and service share increases as exports grow. Finally, the routine cognitive and service worker share declines in firms that increase the imports of goods from abroad (cf. Nilsson Hakkala and Huttunen, 2014). ${ }^{25}$ To conclude, global trade does not seem to have a clear, singular impact on the polarization of the domestic labor market. Instead, the picture is much more nuanced. The endogeneity concern is particularly serious for imports.

To gain a better understanding of these nuanced results, it is instructive to look at the 2SLS regressions by broadly defined industries. Separate estimates for the manufacturing, construction and service industries are reported in Table A5. Perhaps not surprisingly, firms in manufacturing behave differently from those in construction. Manufacturing firms tend to increase their share of routine manual

\footnotetext{
${ }^{25}$ Previous studies have shown that China's WTO membership in 2001 was an important labor market shock that increased competition in the domestic market and destroyed many manufacturing jobs (e.g., Utar, 2018; Keller and Utar, 2016; Nilsson Hakkala and Huttunen, 2016). Utar (2018) also documents within-firm changes in response to increased import competition and shows a net increase in jobs occupied by college educated as well as technical design jobs. Our design is different from those studies, as we analyze the effect of the firms' international trade on occupational polarization. Table A4 reports the reduced form estimates, where we introduce the firm-specific export and import IVs as explanatory variables. These results are in line with those of Utar (2018) and the other studies mentioned above. In particular, increased global import competition reduces the share of routine manual domestic jobs.
} 
workers and reduce their share of routine cognitive and abstract workers as a result of increased exports. In contrast, increased exports positively (negatively) affect the share of routine cognitive and abstract (routine manual) employment in construction firms. The fact that imports and exports often have the same effect on the occupational employment share in manufacturing may indicate that the firms increasing the imports of materials and intermediate goods are likely to increase their exports of final goods. These results can be rationalized by Grossman and Rossi-Hansberg (2008) as well as Baldwin and Robert-Nicoud (2014), who argue that increasing the access to international trade can have domestic welfare effects. In particular, offshoring may actually increase the demand for domestic low-skilled workers.

For an alternative polarization specification, we created a single index to characterize the relative polarization rate at the firm level and used that index as the dependent variable in our regressions. Here, occupations are grouped into 3 groups, combining routine manual and routine cognitive into a single category (G2). The index is calculated as follows:

$$
\mathrm{PI}=\min \left[\mathrm{d}_{\mathrm{G} 1}, \mathrm{~d}_{\mathrm{G} 3}\right]-\mathrm{d}_{\mathrm{G} 2},
$$

where $d_{\mathrm{GN}}$ signals the percentage share change of the occupation group GN share between 2000 and 2014, and the groups are defined as follows: G1 includes abstract jobs, G2 contains routine cognitive and routine manual jobs, and G3 contains the service tasks. A higher PI index is indicative of greater polarization such that the G2 group has experienced lower growth than the other groups.

The 2SLS results using this single polarization index as the dependent variable agree with our findings by occupation group (Table A5). Most importantly, an increase in the trade of goods is negatively associated with overall job polarization at the firm level, especially in manufacturing firms, while an increase in global trade is positively associated with job polarization in construction firms. ${ }^{26}$ Overall, increasing the exports does not seem to have a clear impact on the polarization index, largely

${ }^{26}$ As a final robustness check, we tested an alternative index for job polarization, i.e., $0.5\left(\mathrm{~d}_{\mathrm{G} 1}+\mathrm{d}_{\mathrm{G} 3}\right)-\mathrm{d}_{\mathrm{G} 2}$. The results were again in line with those presented above. 
due to the contrasting effects on abstract versus routine jobs (Table 6). Conversely, increasing the imports of goods actually seems to reduce the overall polarization of the domestic labor market.

Finally, as the tasks within each occupation group may have changed over time, we re-estimated the 2SLS regressions reported in Table 6 using alternative occupation categories. Specifically, we used the ISCO 1-digit occupational classification and defined managers, professionals and technical workers as "abstract workers". Using the same type of approximation, ISCO clerical workers constitute a proxy for routine cognitive workers; craft workers and plant operators correspond to routine manual workers; and elementary and service workers correspond to those performing nonroutine manual tasks. The results are reported in Appendix Table A6 and are largely similar to Table 6.

[Table 6 in here]

\subsection{Polarization and outsourcing}

Panel A of Table 7 reports the OLS regression results for outsourcing. In Panel B, we divide the outsourcing activities more finely, as follows: domestic vs. foreign outsourcing, and planned outsourcing. These different outsourcing variables are introduced separately, although we also tried estimating the correlations simultaneously. The simultaneous regression results are not reported, but they were comparable to the ones presented in the table. As can be expected, the service worker share falls (increases) in firms that outsource some of their activities domestically (abroad). The point estimates indicate that switching from "no outsourcing" to "outsourcing" is connected to a change in the share of service tasks by approximately 3 percentage points, which is quite substantial. As discussed above, these results are probably related to the types of tasks that are being outsourced; domestic outsourcing tends to involve tasks such as cleaning and food services. Correspondingly, the routine manual share increases in firms that outsource domestically but declines in firms that outsource abroad. Again, this result is sensible, as the typical tasks outsourced abroad involve some production of goods. Interestingly, the change in the abstract occupation share shows no significant correlation with any specific type of outsourcing. Below, we provide a more causal interpretation for some of these findings. 
Panels C and D of Table 7 report the 2SLS regression results for outsourcing. Here, the IV performs reasonably well, with the F-statistic exceeding 10 for both overall outsourcing and domestic outsourcing. The F-test value is highest for overall outsourcing (16.16). The 2SLS estimates stand in some contrast to the OLS estimates discussed above. First, they confirm that firms outsourcing domestically are likely to reduce their share of service employment and increase the share of routine manual employment. However, the 2SLS estimates now indicate that firms that outsource domestically also tend to decrease their share of abstract and routine cognitive tasks. In addition to service tasks, the domestic outsourcing data show that domestic outsourcing increasingly includes ICT and administrative services, which could explain the result. Finally, firms that outsource some of their activities abroad are likely to reduce the share of routine manual tasks, and the magnitude of the effect is much larger than in the OLS. Notably, the IV has a weaker performance in this specification, with the F-test value hovering around 6.

Finally, the results using a single polarization index as the dependent variable correspond, for the most part, to the findings by occupation group. In particular, the overall occupational distribution is polarizing in firms that outsource abroad, but not in those firms that outsource domestically. To check for any sensitivity of our results to potential task changes within occupation groups, we again reestimated the 2SLS models for outsourcing using the alternative, ISCO-based, and occupation categories (Table A7). Consistent with the results in Table 7, these estimations show that firms outsourcing abroad are more prone to reduce production employment. However, the effect of domestic outsourcing on the share of nonroutine manual employment is surprisingly positive. To this end, we examined the effect of outsourcing on the shares of service and elementary occupations separately and found that outsourcing firms are more prone to reduce employment, especially from elementary occupations.

[Table 7 in here]

6.4. Auxiliary results on ICT, $R \& D$, and services trade 
To gauge the correlation between other firm traits and occupational restructuring within firms, we used data for international trade in services, as well as the ICT and R\&D surveys. Here, the export (and import) of services is measured as the difference in the log value of export (import) of services between 2000 and 2014. ICT intensity is measured as the initial share of employees using ICT. We also experimented with the change in the share of workers using ICT, although the number of firms drops quite dramatically, as only large firms tend to be surveyed both in 2000 and 2014. R\&D investment is measured as the initial (2001) value of the firm's log of R\&D expenditure per employee. Table 8 presents the results, where Panel A shows the ICT, Panel B shows the R\&D, and Panel C shows the trade in service variables.

Admittedly, these auxiliary results are somewhat harder to compare across specifications, as each survey covers a slightly different sample of firms. Additionally, while interpreting these results, we will not assign a cause-and-effect relationship, and we note that the estimated coefficients are not always statistically significant. With these caveats in mind, there are some interesting relationships that emerge. For example, we find that a greater ICT usage in firms is related to a declining share of mid-skilled and low-skilled employees, while the share of high-skilled employees increases (Panel A). These results correspond to previous evidence from studies focusing on ICT and "skill biased technological change" (e.g., Böckerman et al., 2019; Michaels et al., 2014), as well as to the impact of ICT shocks and broadband adoption of skilled versus unskilled employment (Gaggl and Wright, 2017; Akerman, Gaarder, and Mogstad, 2015). ${ }^{27}$

In Table 8, firms investing more in their R\&D tend to increase their share of abstract workers and reduce their share of routine cognitive and service workers (Panel B). The contribution of R\&D is quite sizeable, as a one percent increase in the firm's internal R\&D spending is associated with an increase (decrease) in the share of abstract (routine cognitive) occupations by 1.7 (1.3) percentage points. These

\footnotetext{
${ }^{27}$ To test the robustness of the ICT and R\&D variables to the inclusion of trade measures and survey sample differences, we take the approach of Bloom et al. (2017) to see whether another factor is driving the relationship. We find that all of the main results are robust to limiting the analysis to the same sample and including two or three measures in the same model. The results of this "horse race" are available from the authors upon request.
} 
results on $R \& D$ investment correspond again to the literature on skill-biased technological change and provide further firm-level evidence of the connection between technology investment and occupational change. Finally, with the international trade of services, we find that firms growing their service exports tend to somewhat increase their share of abstract workers and reduce their share of routine manual workers. The results seem particularly intuitive, as the service exports include, e.g., R\&D, marketing services, accounting, technical support, as well as business and law related services. Conversely, firms growing their imports in services seem to increase their nonroutine manual worker share and reduce their share in production employment and abstract tasks.

[Table 8 in here]

\section{Conclusions}

This paper analyzes job polarization in Finland using unique firm-worker panel data that have been augmented to include measures of goods and services trade, outsourcing and offshoring, as well as technology investment and usage (e.g., R\&D and ICT). We analyze the degree to which job polarization stems from changes inside surviving firms versus firm-level restructuring involving employment reallocation across the establishments of continuing multiunit firms, entries and exits. The pattern varies across occupations; while the increase in high-level abstract occupations comes from changes within firms, firm entry substantially contributes to the increase of service occupations. The routine manual and cognitive occupations are mostly declining within firms and through the entry dynamics.

Following the recent studies by Hummels et al. (2014) and Hakkala and Huttunen (2014, 2016), we develop an IV approach to deal with the endogeneity between occupational changes and the outsourcing, import and export decisions that firms make. Growing exports by the firm are associated with a decline in the share of professional and routine manual occupations but an increasing share of routine cognitive and service occupations. Conversely, the increasing of imports has a significant positive effect on routine manual occupations, perhaps reflecting a source of cheaper intermediate goods 
used in the production process. Firms outsourcing globally tend to reduce workers in routine manual jobs and increase service jobs, whereas firms outsourcing domestically reduce employment in both ends of occupational skill distribution. Increasing ICT use and R\&D investments are also positively linked to the share of abstract, high-skilled occupations.

A comparison of the decomposition and regression analyses provides some interesting observations. First, the increase in high-level abstract jobs is predominantly a within-firm phenomenon and is mostly explained by outsourcing and greater ICT and R\&D intensity. Second, firms that outsource domestically are more prone to lay off service workers. This is consistent with the decomposition results, as the demand for these service tasks in the domestic labor market also generates a greater supply of such tasks; newly established firms show a much higher concentration in low-level service occupations. Third, a significant part of the overall decrease in routine occupations is explained by the within-firm component, and the regression results show that this decrease is linked to decreased international trade, the outsourcing of production functions abroad, and the replacement of routine jobs with computers.

To understand the role of worker mobility in this process, we took a transition matrix approach to characterize the occupational distribution in 2000 versus 2014. We find evidence of occupational upgrading for workers who remain in the same firm as well as for those who move across firms. The share of service occupations is much higher among new labor market entrants relative to those who exit after 2000. These findings indicate a significant role of worker mobility between firms in the story of occupational polarization, warranting further study.

What are the policy lessons learned from this exercise? First, high-level abstract tasks (i.e., "good jobs") are largely created in big surviving firms, whereas low-level service tasks (i.e., "bad jobs") are created in newly established firms. To encourage occupational upgrading, work-to-work training programs could be used to better link the routine workers in those large firms to abstract tasks. Interestingly, the reduction of routine jobs was not occurring at the firm-exit margin, which would make 
it challenging for the routine workers to find a new job after displacement. ${ }^{28}$ Given that the entry component explains a significant part of job polarization, the education policy could more readily respond to exogenous changes in the skill demand in the labor market. For example, more reactive education programs could focus on reducing the number of available study places at state educational institutions in fields threatened by globalization or robotization, and/or increasing the number of available places in, e.g., health care and other personal service fields that will be in high demand due to population aging.

This paper demonstrates the importance of including the firm and firm dynamics in the analyses of aggregate labor market trends. While it is true that job polarization exists at the level of the labor market, the mechanisms and driving forces are quite different for each occupation. This is particularly important when considering policy measures and other potential responses to job polarization that are pervasive in developed countries. We have taken the first step at describing the firm- and establishmentlevel patterns linked with worker mobility that underlies the aggregate labor market polarization and in establishing a causal link between firm-level polarization and the various international activities that firms engage in. Much work is still required to fully understand the specific mechanisms and links at the firm level, and the data available in Finland (and other Nordic countries) provide opportunities for future research to delve into those questions.

\section{References}

Akerman, A., I. Gaarder, and M. Mogstad (2015). The Skill Complementarity of Broadband Internet. Quarterly Journal of Economics 130(4), 1781-1824.

\footnotetext{
${ }^{28}$ Indeed, this result is consistent with the new study by Maczulskij (2019), who finds that routine manual workers exit the labor market mainly through unemployment, instead of moving from employment to retirement.
} 
Acemoglu, D. and D. Autor (2011). Chapter 12 - Skills, Tasks and Technologies: Implications for Employment and Earnings. Volume 4, pp. 1043-1171. Elsevier.

Autor, D. (2010). The Polarization of Job Opportunities in the U.S. Labor Market. Report. Center for the American Progress and the Hamilton Project, Washington DC.

Autor, D., F. Levy, and R. Murnane (2003). The Skill Content of Recent Technological Change: An empirical exploration. Quarterly Journal of Economics 118 (4): 1279-1333.

Autor, D. H., L. F. Katz, and M. S. Kearney (2006). The Polarization of the US Labor Market. The American Economic Review 96 (2): 189-194.

Baldwin, R. and F. Robert-Nicoud (2014). Trade-in-Goods and Trade-in-Tasks: An Integrating Framework. Journal of International Economics 92(1): 51-62.

Bartel, A., C. Ichniowski, and K. Shaw (2007). How Does Information Technology Affect Productivity? Plant-Level Comparisons of Product Innovation, Process Improvement, and Worker Skills. Quarterly Journal of Economics 122(4), 1721-1758.

Bartelsman, E., J. Haltiwanger, and S. Scarpetta. (2013). Cross-Country Differences in Productivity: The Role of Allocation and Selection. American Economic Review, 103(1), 305-334.

Bloom, N., R. Sadun, and J. Van Reenen. (2016). Management as a Technology? NBER, Working Paper No. 22327.

Bloom, N., E. Brynjolfsson, L. Foster, R.S. Jarmin, M. Patnaik, I. Saporta-Eksten, J. Van Reenen. (2017). What Drives Differences in Management Practices? NBER Working Paper 23300.

Böckerman, P, S. Laaksonen, and J. Vainionmäki (2019) Does ICT Usage Erode Routine Occupations at the Firm Level? Labour, 33, 26-47.

Böckerman, P. and M. Maliranta (2013). Outsourcing, Occupational Restructuring, and Employee WellBeing: Is There a Silver Lining? Industrial Relations: A Journal of Economy and Society, 52(4), $878-914$. 
Cortes, G.M. and A. Salvatori (2015) Task Specialization within Establishments and the Decline of Routine Employment. Mimeo.

Crinò, R. (2010). Service Offshoring and White-Collar Employment. The Review of Economic Studies, 77(2): 595-632.

Davis, D.R. and J. Harrigan (2011). Good Jobs, Bad Jobs, and Trade Liberalization. Journal of International Economics 84(1): 26-36.

Gaggl, P. and G.C. Wright (2017). A Short-Run View of What Computers Do: Evidence from a UK Tax Incentive. American Economic Journal: Applied Economics 9(3): 262-94.

Goos, M. and A. Manning (2007). Lousy and Lovely Jobs: The Rising Polarization of Work in Britain. The Review of Economics and Statistics 89 (1): 118-133.

Goos, M., A. Manning, and A. Salomons (2009). Job polarization in Europe. American Economic Review 99 (2): 58-63.

Goos, M., A. Manning, and A. Salomons (2014). Explaining Job Polarization: Routine-Biased Technological Change and Offshoring. American Economic Review 104(8): 2509-2526.

Grossman, G.M. and E. Rossi-Hansberg (2008). Trading Tasks: A Simple Theory of Offshoring. American Economic Review 98(5): 1978-97.

Haller, S. A., Damijan, J., Kaitila, V., Kostevc, Č., Maliranta, M., Milet, E., Mirza D., Rojec, M. (2014). Trading Firms in the Services Sectors: Comparable Evidence from Four EU Countries. Review of World Economics: 1-35.

Harrigan, J., A. Reshef and F. Toubal (2016) The March of the Techies: Technology, Trade, and Job Polarization in France, 1994-2007. NBER Working Paper 22110.

Harrigan, J., A. Reshef and F. Toubal (2018) Techies, Trade, and Skill-Biased Productivity. NBER Working Paper 25295.

Heyman, F. (2016) Job Polarization, Job Tasks and the Role of Firms. Economics Letters 145: 246-251. 
Hummels, D., R. Jorgensen, J. Munch, and C. Xiang (2014) The Wage Effects of Offshoring: Evidence from Danish Matched Worker-Firm Data. American Economic Review 104 (6): 1597-1629.

Hyytinen, A. and M. Maliranta (2013). Firm Lifecycles and Evolution of Industry Productivity. Research Policy, 42(5).

Kauhanen, A. and M. Maliranta (2019). The Roles of Job and Worker Restructuring in Aggregate Wage Growth Dynamics. Review of Income \& Wealth 65(1): 99-118.

Keller, W. and H. Utar (2016). International Trade and Job Polarization: Evidence at the Worker Level. NBER Working Paper 22315.

Maczulskij, T. (2019). Occupational Mobility of Routine Workers. Labour Institute for Economic Research working Papers No. 327.

Maliranta, M. (2013). Globalization, Occupational Restructuring and Firm Performance. ETLA Discussion Papers No. 5.

Maksimovic, V. and G. Phillips (2002). Do Conglomerate Firms Allocate Resources Inefficiently Across Industries? Theory and Evidence. Journal of Finance 57: 721-767.

Michaels, G., A. Natraj, and J. Van Reenen (2014). Has ICT Polarized Skill Demand? Evidence from Eleven Countries Over 25 Years. Review of Economics and Statistics 96 (1): 60-77.

Mishel, L., H. Shierholz, and J. Schmitt (2013). Don’t Blame the Robots: Assessing the Job Polarization Explanation of Growing Wage Inequality. EPI-CEPR Working Paper, November 2013.

Mitrunen, M. (2013) Työmarkkinoiden polarisaatio Suomessa. Government Institute for Economic Research Memorandum 33. ("Polarization of the Labor Market in Finland”, in Finnish).

Nilsson Hakkala, K. and K. Huttunen (2014) Displacing Tasks: Understanding the Employment Effects of Offshoring, mimeo.

Nilsson Hakkala, K. and K. Huttunen (2016) Worker Level Consequences of Import Shocks, VATT Working Paper 74. 
Oesch, D. and J. Rodriguez Menes (2010) Upgrading or polarization? Occupational change in Britain, Germany, Spain and Switzerland, 1990-2008. MPRA Paper 21040.

Olsson, M. and J. Tåg (2017). Private Equity, Layoffs, and Job Polarization. Journal of Labor Economics 35(3): 697-754.

Statistics Denmark, Statistics Finland, Statistics Netherlands, Statistics Norway, and Statistics Sweden (2008). International Sourcing: Moving Business Functions Abroad. Statistics Denmark, Copenhagen.

Utar, H. (2018). Workers Beneath the Floodgates: The Impact of Low-Wage Import Competition and Workers' Adjustment. Review of Economics and Statistics (forthcoming).

Van Reenen, J. (2011). Wage inequality, technology and trade: 21st century evidence. Labour Economics 18 (6): 730-741.

Vainiomäki, J. (1999). "Technology and Skill Upgrading: Results from Linked Worker-Plant Data for Finnish Manufacturing. In: Haltiwanger, J., Lane, J., Spletzer, J.R., Theuwes, J.J.M., and Troske, K.R (Eds.). The creation and analysis of employer-employee matched data. Elsevier Science, North-Holland, Amsterdam; New York and Oxford, pp. 115-145. 
Table 1: Characteristics of workers by task group, 2000 and

\begin{tabular}{|c|c|c|c|c|c|c|c|c|c|c|c|c|c|c|c|}
\hline & \multicolumn{3}{|c|}{$\begin{array}{c}\text { Share of highly } \\
\text { educated, } \%\end{array}$} & \multicolumn{3}{|c|}{$\begin{array}{c}\text { Mean years of } \\
\text { education }\end{array}$} & \multicolumn{3}{|c|}{ Share of women, $\%$} & \multicolumn{3}{|c|}{ Mean age } & \multicolumn{3}{|c|}{ Mean annual earnings, $€$} \\
\hline & 2000 & 2014 & Change & 2000 & 2014 & Change & 2000 & 2014 & Change & 2000 & 2014 & Change & 2000 & 2014 & Change \\
\hline $\begin{array}{l}\text { Abstract } \\
\text { Routine }\end{array}$ & $75 \%$ & $80 \%$ & $5 \%$ & 14.7 & 15.5 & 0.8 & $44 \%$ & $48 \%$ & $4 \%$ & 41.7 & 43.6 & 1.9 & 45,784 & 52,201 & $14 \%$ \\
\hline cognitive & $40 \%$ & $41 \%$ & $1 \%$ & 12.3 & 13.0 & 0.7 & $76 \%$ & $74 \%$ & $-2 \%$ & 40.9 & 40.8 & -0.1 & 27,020 & 29,228 & $8 \%$ \\
\hline Routine manual & $5 \%$ & $7 \%$ & $2 \%$ & 11.1 & 11.6 & 0.5 & $18 \%$ & $15 \%$ & $-3 \%$ & 39.7 & 41.1 & 1.4 & 30,405 & 34,643 & $14 \%$ \\
\hline Service & $9 \%$ & $15 \%$ & $6 \%$ & 11.4 & 12.1 & 0.7 & $78 \%$ & $77 \%$ & $-1 \%$ & 41.3 & 41.9 & 0.6 & 22,309 & 26,043 & $17 \%$ \\
\hline
\end{tabular}

Note: Employees who worked in firms that had at least 10 employees during observation year 2000/2014 
Table 2: Descriptive statistics for total FLEED by firm type, 2000 and 2014

Number of firms

Number of employees

Continuing firms

Entering

firms

Exiting

2000

2014

$6,314 \quad 6,314$

$\begin{array}{r}\mathbf{2 0 1 4} \\ \hline 5,736\end{array}$

firms

$490,419 \quad 524,927$

$42 \% \quad 43 \%$

323,299

$45 \%$

39.8

2000

$39.9 \quad 41.8$

37,959

5,079

Female, \%

Age

Mean earnings per year, $€$

35,236 41,062

Primary education, \%

Secondary education, $\%$

$23 \% \quad 11 \%$

$12 \%$

$50 \%$

342,222

$45 \% \quad 49 \%$

$11 \%$

$16 \%$

$40 \%$

$18 \% \quad 12 \%$

$11 \%$

39.1

$7 \% \quad 16 \%$

$7 \% \quad 12 \%$

$34 \%$

$29 \% \quad 35 \%$

$23 \% \quad 23 \%$

$21 \%$

35,767

$36 \% \quad 30 \%$

$26 \%$

$23 \%$

$45 \%$

$17 \%$

$8 \%$

$7 \%$

Abstract, \%

$12 \%$

$12 \%$

$19 \%$

$31 \%$

$20 \%$

$38 \%$

Service, \%

Note: Employees who worked in firms that had at least 10 employees during observation year 2000/2014. Workers with zero earnings and/or less than six employment months during observation year are excluded. 
Total goods export, annual (2000-14)

Total goods import, annual (2000-14)

Total services export, annual (2000-14)

Total services import, annual (2000-14)

Total R\&D expenditure in 2000 / worker, $€$ [unweighted]

Total R\&D expenditure in 2000 / worker, $€$ [weighted]

Share of workers that use ICT in 2001, \%

Share of workers that use ICT in 2014, \%

Share of workers that use ICT, \%-point change (2001 to 2014)

Share of firms outsourcing (2001-06), \% [unweighted]

Share of firms outsourcing (2001-06), \% [weighted]

Share of firms planning to outsource (2001-06), \% [unweighted]

Share of firms planning to outsource (2001-06), \% [weighted]

Share of firms outsourcing in Finland (2001-06), \% [unweighted]

Share of firms outsourcing in Finland (2001-06), \% [weighted]

Share of firms outsourcing abroad (2001-2006), \% [unweighted]

Share of firms outsourcing abroad (2001-2006), \% [weighted]

\begin{tabular}{|c|c|c|c|c|}
\hline Data source & Firms & $\begin{array}{r}\text { Mean } \\
\text { (total } \\
\text { value) }\end{array}$ & $\begin{array}{r}\text { Mean } \\
\text { (total value } \\
\text { if }>0 \text { ) }\end{array}$ & Mean (log) \\
\hline Customs data & 6,314 & 3.99 M. $€$ & 16.3 M. $€$ & 4.34 \\
\hline Customs data & 6,314 & 3.14 M. $€$ & 10.5 M. $€$ & 5.21 \\
\hline Services data & 6,309 & 5.31 M. € & 18.6 M. $€$ & 1.61 \\
\hline Services data & 6,309 & 4.17 M. € & 9.74 M. $€$ & 2.15 \\
\hline \multirow[t]{2}{*}{ R\&D survey } & 1,111 & $6,035 €$ & $11,512 €$ & 4.25 \\
\hline & 1,345 & $5,781 €$ & $11,438 €$ & 4.05 \\
\hline \multirow[t]{2}{*}{ ICT survey } & 1,052 & $58 \%$ & & \\
\hline & 1,344 & $76 \%$ & & \\
\hline ICT survey & 484 & $19 \%$-points & $(79 \%-60 \%)$ & \\
\hline \multirow[t]{2}{*}{ Sourcing survey } & 747 & $58 \%$ & & \\
\hline & 1,356 & $53 \%$ & & \\
\hline \multirow[t]{2}{*}{ Sourcing survey } & 747 & $7 \%$ & & \\
\hline & 1,356 & $6 \%$ & & \\
\hline \multirow[t]{2}{*}{ Sourcing survey } & 747 & $46 \%$ & & \\
\hline & 1,356 & $44 \%$ & & \\
\hline \multirow[t]{2}{*}{ Sourcing survey } & 747 & $21 \%$ & & \\
\hline & 1,356 & $17 \%$ & & \\
\hline
\end{tabular}

Note: Firms that had at least 10 employees during years 2000 and 2014 are included. Workers with zero earnings and/or less than six employment months during the observation year are excluded. Weighted means and number of firms are calculated using survey weights (Note: ICT 2001 survey does not contain survey weights). Share of workers that use ICT, \%-point change (2001 to 2014) calculated for firms that were surveyed both in 2001 and 2014. 
Table 4: Decomposition of change in employment share (\%-points) by occupation task group (2000 to 2014).

\begin{tabular}{lccccc}
\hline Panel A: & Total change & Within & Between & Entry & Exit \\
Firm-level data & & & & & \\
Abstract & 5.0 & 6.6 & -1.4 & 1.9 & -2.1 \\
Routine cognitive & -0.8 & -1.1 & 2.2 & -3.6 & 1.7 \\
Routine manual & -5.8 & -3.5 & -2.4 & -7.1 & 7.2 \\
Service & 1.6 & -2.0 & 1.6 & 8.8 & -6.8 \\
& & & & & Exit \\
Panel B: & Total change & Within & Between & Entry & Establishment-level data \\
Abstract & 5.0 & 5.1 & -1.3 & 1.6 & -0.4 \\
Routine cognitive & -0.8 & -0.9 & 1.0 & -2.6 & 1.7 \\
Routine manual & -5.8 & -2.7 & 1.0 & -7.3 & 3.2 \\
Service & 1.6 & -1.5 & -0.7 & 8.3 & -4.5 \\
\hline
\end{tabular}

Note: Private firms/establishments that had at least one employee during observation year 2000 and/or 2014 are included. 
Table 5: Occupational Transition Between 2000 and 2014, Within and Between Firms

\begin{tabular}{|c|c|c|c|c|c|}
\hline \multirow{7}{*}{ 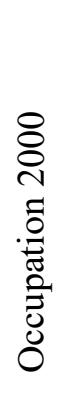 } & & \multicolumn{4}{|c|}{ Occupation 2014} \\
\hline & & Abstract & $\mathrm{RC}$ & $\mathrm{RM}$ & Service \\
\hline & \multicolumn{5}{|l|}{ Panel A: Within Firms } \\
\hline & Abstract & $85 \%$ & $9 \%$ & $5 \%$ & $1 \%$ \\
\hline & $\mathrm{RC}$ & $27 \%$ & $67 \%$ & $3 \%$ & $3 \%$ \\
\hline & $\mathrm{RM}$ & $11 \%$ & $4 \%$ & $84 \%$ & $1 \%$ \\
\hline & Service & $11 \%$ & $12 \%$ & $6 \%$ & $71 \%$ \\
\hline \multirow{6}{*}{ 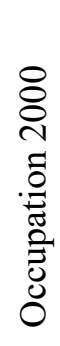 } & & Abstract & $\mathrm{RC}$ & $\mathrm{RM}$ & Service \\
\hline & Panel B: Between Firms & & & & \\
\hline & Abstract & $86 \%$ & $7 \%$ & $3 \%$ & $4 \%$ \\
\hline & $\mathrm{RC}$ & $29 \%$ & $59 \%$ & $4 \%$ & $8 \%$ \\
\hline & $\mathrm{RM}$ & $17 \%$ & $8 \%$ & $64 \%$ & $11 \%$ \\
\hline & Service & $15 \%$ & $10 \%$ & $5 \%$ & $70 \%$ \\
\hline \multirow{7}{*}{ 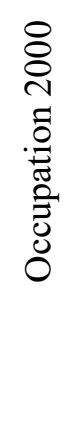 } & Panel C: Exiting Workers & \multicolumn{4}{|c|}{ Not Present in 2014} \\
\hline & Abstract & $29 \%$ & & & \\
\hline & $\mathrm{RC}$ & $20 \%$ & & & \\
\hline & $\mathrm{RM}$ & $30 \%$ & & & \\
\hline & Service & $21 \%$ & & & \\
\hline & Panel D: Entering Workers & Abstract & $\mathrm{RC}$ & $\mathrm{RM}$ & Service \\
\hline & Not Present in 2000 & $31 \%$ & $21 \%$ & $21 \%$ & $27 \%$ \\
\hline & $\begin{array}{l}\text { s: Of the } 2.35 \text { million emplo } \\
2000 \text {, and } 33 \% \text { are present } \\
\text { ne same employer while } 84 \% \\
\text { ution for workers that exited } \\
\text { workers that entered by } 2014\end{array}$ & $\begin{array}{l}\text { a, about } 35 \\
\text { Of those p } \\
\text { s. Panel C } \\
\text { ile Panel C }\end{array}$ & $\begin{array}{l}\text { only } \\
t \text { in bc } \\
\text { s the } \\
\text { lays } t\end{array}$ & $\begin{array}{l}\text { ent in } \\
\text { ars, } 1 \\
\text { occup } \\
14 \text { dis }\end{array}$ & $\begin{array}{l}4,32 \% \\
\text { remained } \\
\text { nal } \\
\text { ution for }\end{array}$ \\
\hline
\end{tabular}


Table 6: Firm-level OLS and 2SLS regressions for change in occupation share between 2000 and 2014. International trade of goods.

\begin{tabular}{|c|c|c|c|c|c|}
\hline Explanatory variable & Abstract & $\begin{array}{l}\text { Routine } \\
\text { cognitive }\end{array}$ & $\begin{array}{l}\text { Routine } \\
\text { manual }\end{array}$ & Service & $\begin{array}{l}\text { Polarization } \\
\text { index }\end{array}$ \\
\hline \multicolumn{6}{|l|}{ Panel A: OLS regression } \\
\hline Change in export of goods & $\begin{array}{l}-0.0096 * * * \\
(0.0005)\end{array}$ & $\begin{array}{l}-0.0015 * * * \\
(0.0005)\end{array}$ & $\begin{array}{l}0.0124 * * * \\
(0.0005)\end{array}$ & $\begin{array}{l}-0.0013 * * * \\
(0.0003)\end{array}$ & $\begin{array}{l}-0.0123 * * * \\
(0.0008)\end{array}$ \\
\hline Change in import of goods & $\begin{array}{l}-0.0083 * * * \\
(0.0005)\end{array}$ & $\begin{array}{l}-0.0006 \\
(0.0004)\end{array}$ & $\begin{array}{l}0.0062 * * * \\
(0.0004)\end{array}$ & $\begin{array}{l}0.0027 * * * \\
(0.0003)\end{array}$ & $\begin{array}{l}-0.0033 * * * \\
(0.0007)\end{array}$ \\
\hline $\begin{array}{l}\text { Panel B: IV regression } \\
\text { Change in export of goods, } \\
2 \mathrm{SLS}\end{array}$ & $\begin{array}{l}-0.0094 * * * \\
(0.0035)\end{array}$ & $\begin{array}{l}0.0116 * * * \\
(0.0036)\end{array}$ & $\begin{array}{l}-0.0101 * * * \\
(0.0038)\end{array}$ & $\begin{array}{l}0.0079 * * * \\
(0.0023)\end{array}$ & $\begin{array}{c}0.0067 \\
(0.0054)\end{array}$ \\
\hline $\begin{array}{l}\text { Change in import of goods, } \\
\text { 2SLS }\end{array}$ & $\begin{array}{l}-0.0047 \\
(0.0032)\end{array}$ & $\begin{array}{l}-0.0164 * * * \\
(0.0032)\end{array}$ & $\begin{array}{l}0.0263 * * * \\
(0.0034)\end{array}$ & $\begin{array}{l}-0.0052 * * \\
(0.0021)\end{array}$ & $\begin{array}{l}-0.0155 * * * \\
(0.0049)\end{array}$ \\
\hline $\begin{array}{ll} & 1 \text { st stage, } \\
\text { export } & 1 \text { st stage, } \\
\text { import } & \end{array}$ & \multicolumn{4}{|c|}{ iv_exp: $0.770 * * *(0.043)$, iv_imp: $0.832 * * *(0.047)$} & $\begin{array}{l}\text { Joint C-D F- } \\
\text { test: } 56.48\end{array}$ \\
\hline Number of firms & $\begin{array}{l}6,314 \\
0.041\end{array}$ & $\begin{array}{l}6,314 \\
0.002\end{array}$ & $\begin{array}{l}6,314 \\
-0.028\end{array}$ & $\begin{array}{l}6,314 \\
-0.015\end{array}$ & $\begin{array}{l}6,314 \\
-0.039\end{array}$ \\
\hline Mean (std) of dep. variable & $\begin{array}{l}(0.162) \\
-0.203\end{array}$ & $(0.158)$ & $(0.145)$ & $(0.117)$ & $(0.278)$ \\
\hline Mean (std) of export & $\begin{array}{c}(4.035) \\
0.319\end{array}$ & & & & \\
\hline Mean (std) of import & $(4.087)$ & & & & \\
\hline Standardized coefficients & & & & & \\
\hline OLS: Exports & $-0.0387 * * *$ & $-0.0060 * * *$ & $0.0499 * * *$ & $-0.0052 * * *$ & $-0.0498 * * *$ \\
\hline OLS: Imports & $-0.0339 * * *$ & -0.0026 & $0.0254 * * *$ & $0.0110 * * *$ & $-0.0136 * * *$ \\
\hline IV: Exports & $-0.0378 * * *$ & $0.0468 * * *$ & $-0.0407 * * *$ & $0.0317 * * *$ & -0.0634 \\
\hline IV: Imports & -0.0194 & $-0.0669 * * *$ & $0.1076^{* * *}$ & $-0.0213 * *$ & $0.0272 * * *$ \\
\hline
\end{tabular}

Notes: The total number of employees in the firm in 2000 is used to weight the observations. *** ( $<<0.01)$, ** $(p<0.05)$ and $*(p<0.10)$. Standard errors in parentheses. Other controls: average age of employees, average wage of employees and industry dummies in 2000. 
Table 7: Firm-level OLS and 2SLS regressions for change in occupation share between 2000 and 2014. Outsourcing.

\begin{tabular}{|c|c|c|c|c|c|}
\hline Explanatory variable & Abstract & $\begin{array}{l}\text { Routine } \\
\text { cognitive }\end{array}$ & $\begin{array}{l}\text { Routine } \\
\text { manual }\end{array}$ & Service & $\begin{array}{l}\text { Polarization } \\
\text { index }\end{array}$ \\
\hline \multicolumn{6}{|l|}{ Panel A: Outsourcing, OLS } \\
\hline Outsourcing/Offshoring & $\begin{array}{l}0.0473 * * * \\
(0.0166)\end{array}$ & $\begin{array}{l}-0.0028 \\
(0.0150)\end{array}$ & $\begin{array}{l}-0.0200 \\
(0.0163)\end{array}$ & $\begin{array}{l}-0.0245 * * * \\
(0.0088)\end{array}$ & $\begin{array}{l}-0.0046 \\
(0.0231)\end{array}$ \\
\hline \multicolumn{6}{|c|}{ Panel B: Domestic outsourcing, abroad versus planned, OLS } \\
\hline Domestic outsourcing & $\begin{array}{l}0.0024 \\
(0.0154)\end{array}$ & $\begin{array}{l}-0.0080 \\
(0.0139)\end{array}$ & $\begin{array}{l}0.0360 * * \\
(0.0150)\end{array}$ & $\begin{array}{l}-0.0304 * * * \\
(0.0081)\end{array}$ & $\begin{array}{l}-0.0616 * * * \\
(0.0212)\end{array}$ \\
\hline Outsourcing abroad & $\begin{array}{l}0.0139 \\
(0.0174)\end{array}$ & $\begin{array}{l}0.0133 \\
(0.0156)\end{array}$ & $\begin{array}{l}-0.0721 * * * \\
(0.0167)\end{array}$ & $\begin{array}{l}0.0450 * * * \\
(0.0091)\end{array}$ & $\begin{array}{l}0.0981 * * * \\
(0.0238)\end{array}$ \\
\hline Plan to outsource 2007- & $\begin{array}{l}0.0178 \\
(0.0237)\end{array}$ & $\begin{array}{l}0.0650 * * * \\
(0.0212)\end{array}$ & $\begin{array}{l}-0.0467 * * \\
(0.023)\end{array}$ & $\begin{array}{l}-0.0361 * * * \\
(0.0125)\end{array}$ & $\begin{array}{l}-0.0433 \\
(0.0327)\end{array}$ \\
\hline \multicolumn{6}{|l|}{ Panel C: Outsourcing, IV } \\
\hline \multirow[t]{2}{*}{ Outsourcing / offshoring } & $\begin{array}{l}-0.1602 * \\
(0.0886)\end{array}$ & $\begin{array}{l}-0.1545 * * \\
(0.0776)\end{array}$ & $\begin{array}{l}0.3395 * * * \\
(0.1015)\end{array}$ & $\begin{array}{l}-0.0248 \\
(0.0428)\end{array}$ & $\begin{array}{l}-0.2269 * \\
(0.1187)\end{array}$ \\
\hline & iv_exp: 0.177 & $* * *(0.031)$, iv_in & p: $0.004(0.027)$ & F-test: 16.16 & \\
\hline \multicolumn{6}{|c|}{ Panel D: Domestic outsourcing, abroad versus planned, IV } \\
\hline \multirow[t]{2}{*}{ Domestic outsourcing } & $\begin{array}{l}-0.2003 * * \\
(0.0970)\end{array}$ & $\begin{array}{l}-0.1658 * \\
(0.0851)\end{array}$ & $\begin{array}{l}0.4447 * * * \\
(0.1201)\end{array}$ & $\begin{array}{l}-0.0786 * \\
(0.0471)\end{array}$ & $\begin{array}{l}-0.3727 * * * \\
(0.1364)\end{array}$ \\
\hline & iv_exp: 0.160 & 0.034), iv_imp: - & $.028(0.029), \mathrm{F}$ & test: 11.72 & \\
\hline \multirow[t]{2}{*}{ Outsourcing abroad } & $\begin{array}{l}0.1773 \\
(0.1455)\end{array}$ & $\begin{array}{l}-0.0171 \\
(0.1240)\end{array}$ & $\begin{array}{l}-0.5136 * * * \\
(0.1846)\end{array}$ & $\begin{array}{l}0.3533 * * * \\
(0.1152)\end{array}$ & $\begin{array}{l}0.8601 * * * \\
(0.2912)\end{array}$ \\
\hline & iv_exp: 0.013 & (0.030), iv_imp: ( & $089 * * *(0.026$ & , F-test: 5.89 & \\
\hline \multirow[t]{2}{*}{ Plan to outsource 2007- } & $\begin{array}{l}-0.7143 \\
(0.4725)\end{array}$ & $\begin{array}{l}-0.2968 \\
(0.3292)\end{array}$ & $\begin{array}{l}1.8010 * \\
(0.946)\end{array}$ & $\begin{array}{l}-0.7899 * * \\
(0.4011)\end{array}$ & $\begin{array}{l}-2.2811 * \\
(1.1678)\end{array}$ \\
\hline & iv_exp: 0.020 & (0.022), iv imp: - & $.035 *(0.019)$ & F-test: 2.11 & \\
\hline Number of firms & 747 & 747 & 747 & 747 & 747 \\
\hline Mean (std) of dependent variable & $0.071(0.170)$ & $-0.007(0.153)$ & $-0.04(0.182)$ & $-0.024(0.075)$ & $-0.004(0.257)$ \\
\hline Mean (std) of outsourcing & $0.584(0.493)$ & {$[0.534(0.499)]$} & & & \\
\hline Mean (std) of dom. outsourcing & $0.459(0.499)$ & {$[0.436(0.496)]$} & & & \\
\hline Mean (std) of outsourcing abroad & $0.213(0.410)$ & {$[0.169(0.375)]$} & & & \\
\hline Mean (std) of plant to outsource & $0.074(0.261)$ & {$[0.062(0.241)]$} & & & \\
\hline \multicolumn{6}{|l|}{ Standardized coefficients } \\
\hline IV: Outsourcing (Panel C) & $-0.0790 *$ & $-0.0762 * *$ & $0.1674 * * *$ & -0.0122 & $-0.1119 *$ \\
\hline IV: Domestic outsourcing & $-0.0998 * *$ & $-0.0827 *$ & $0.2217 * * *$ & $-0.0392 *$ & $-0.1858 * * *$ \\
\hline IV: Outsource abroad & 0.0726 & -0.0070 & $-0.2104 * * *$ & $0.1447 * * *$ & $0.3523 * * *$ \\
\hline IV: Plan to outsource & -0.1867 & -0.0776 & $0.4707^{*}$ & $-0.2064 * *$ & $-0.5961 *$ \\
\hline
\end{tabular}

Notes: The total number of employees in the firm in 2000 is used to weight the observations. $* * *(p<0.01),{ }^{* *}(\mathrm{p}<0.05)$ and $*(p<0.10)$. Standard errors in parentheses. Other controls: average age of employees, average wage of employees and industry dummies in 2000. Means and standard deviations in brackets are calculated using survey weights. 
Table 8: Firm-level OLS regressions for change in occupation share between 2000 and 2014. International trade of goods and services, ICT and R\&D

Explanatory variable

\section{Panel A: ICT Use}

i) \% Workers use computer in 2001

Number of firms

Mean (std) of dependent variable

Mean (std) of \% workers use ICT

Standardized coefficients

$\%$ Workers use computer in 2001

ii) Change (\% Workers use comp.)

Number of firms

Mean (std) of dependent variable

Mean (std) of $\Delta$ (workers use ICT)

Standardized coefficients

\begin{tabular}{lllll} 
Abstract & $\begin{array}{l}\text { Routine } \\
\text { cognitive }\end{array}$ & $\begin{array}{l}\text { Routine } \\
\text { manual }\end{array}$ & Service & $\begin{array}{l}\text { Polarization } \\
\text { index }\end{array}$ \\
\hline & & & & \\
$-0.0004 * *$ & -0.0002 & -0.00001 & $0.0006 * * *$ & $0.0008 * * *$ \\
$(0.0002)$ & $(0.0002)$ & $(0.0002)$ & $(0.0001)$ & $(0.0003)$
\end{tabular}

$1,052 \quad 1,052 \quad 1,052$

$1,052 \quad 1,052$

$0.063(0.158)$

$-0.003(0.149)$

$-0.039(0.176)$

$-0.021(0.089)$

$-0.008(0.249)$

$57.7(0.353)$

\begin{tabular}{lllll}
$-0.0137 * *$ & -0.0054 & -0.0029 & $0.0221 * * *$ & $0.0299 * * *$ \\
\hline $0.0012 * * *$ & -0.0001 & $-0.0007 * *$ & $-0.0004 * *$ & 0.0005 \\
$(0.0003)$ & $(0.0002)$ & $(0.0003)$ & $(0.0002)$ & $(0.0005)$ \\
484 & 484 & 484 & 484 & 484 \\
$0.063(0.154)$ & $-0.007(0.147)$ & $-0.028(0.181)$ & $-0.028(0.089)$ & $-0.016(0.252)$ \\
$18.8(29.721)$ & {$[18.2(30.702)]$} & & &
\end{tabular}

Change (\% Workers use computer)

$0.0350 * * *$

$-0.0035$

$-0.0208^{* *}$

$-0.0107^{* *}$

0.0135

\section{Panel B: R\&D Investment}

$L n(R \& D$ expenditure in 2000)

$\begin{array}{lllll}0.0167 * * * & -0.0129 * * * & 0.0033 & -0.0072 * * * & 0.0031 \\ (0.0019) & (0.0013) & (0.0020) & (0.0006) & (0.0021)\end{array}$

Number of firms

Mean (std) of dependent variable

1,111

1,111

1,111

1,111

1,111

Mean (std) of $\operatorname{Ln}(\mathrm{R} \& D)$

$0.062(0.163)$

-0.007 (0.113)

$-0.047(0.178)$

$-0.008(0.043)$

$0.014(0.224)$

Standardized coefficients

Ln(R\&D expenditure in 2001)

$4.235(4.220)$

[4.052 (4.217)]

$0.0706^{* * *}$

$-0.0543 * * *$

0.0140

$-0.0304 * * *$

0.0131

Panel C: Trade in service variables

Change in exp. of services (2001-14)

$0.0024 * * * \quad 0.0002$

$-0.0009 * *$

$-0.0016 * * *$

$-0.0006$

$(0.0005)$

(0.0004)

(0.0004)

$(0.0003)$

$(0.0007)$

Change in imp. of services (2001-14)

$-0.0026 * * *$

$0.0043 * * *$

$-0.0021 * * *$

$0.0004 *$

$-0.0017 * * *$

$(0.0008) \quad(0.0004)$

(0.0004)

(0.0002)

(0.0006)

Number of firms

6,309

6,309

6,309

6,309

6,309

$0.041(0.161)$

$0.002(0.158)$

$-0.028(0.145)$

$-0.015(0.117)$

$-0.040(0.278)$

Mean (std) of $\Delta$ export of services

$0.609(3.660)$

$0.678(4.077)$

Mean (std) of $\Delta$ import of services

Standardized coefficients

Change in exp. of serv. (2001-14)

$0.0086^{* * *} \quad 0.0006$

$-0.0034 * *$

$-0.0059 * * *$

$-0.0023$

Change in imp. of serv. (2001-14)

$-0.0106 * * *$

$0.0174 * * *$

$-0.0087 * * *$

$0.0018^{*}$

$-0.0068 * * *$

Notes: The total number of employees in the firm in 2000 is used to weight the observations. *** is statistically significant at least at the $1 \%$ significance level. Standard errors in parentheses. Other controls: average age of employees, average wage of employees and industry dummies in 2000. Means and standard deviations in brackets are calculated using survey weights (for the 2001 ICT survey no weights are provided). 
Figure 1: Change in employment shares (in \%-points) by 1-digit occupation group (between 2000 and 2014)

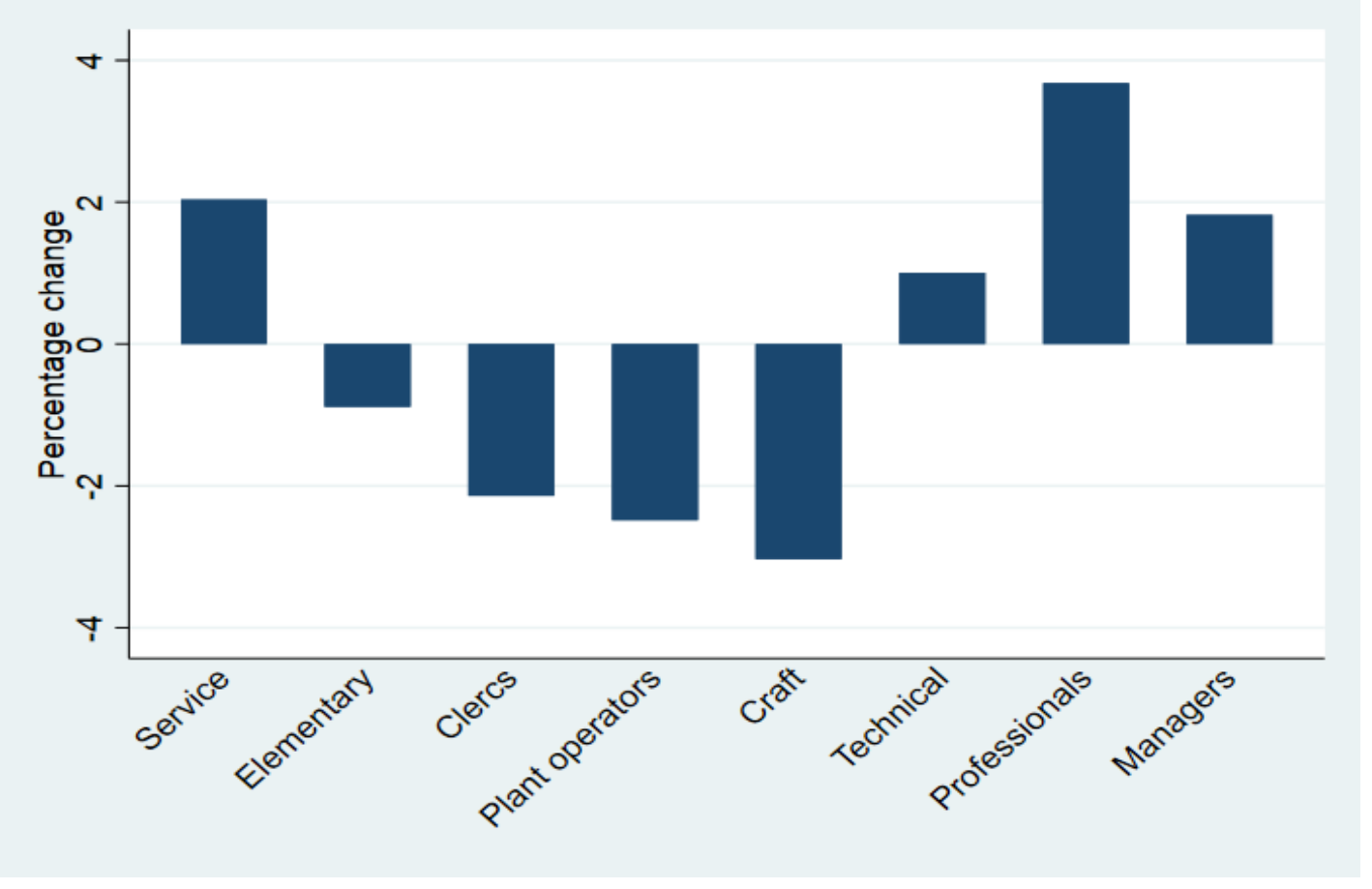

Notes: Includes all employees in the private and public sector, as well as self-employed individuals regardless of establishment size. 
Figure 2: Smoothed change in employment shares (in \%-points) by 2-digit occupation group ranked by initial mean wage (between 2000 and 2014)

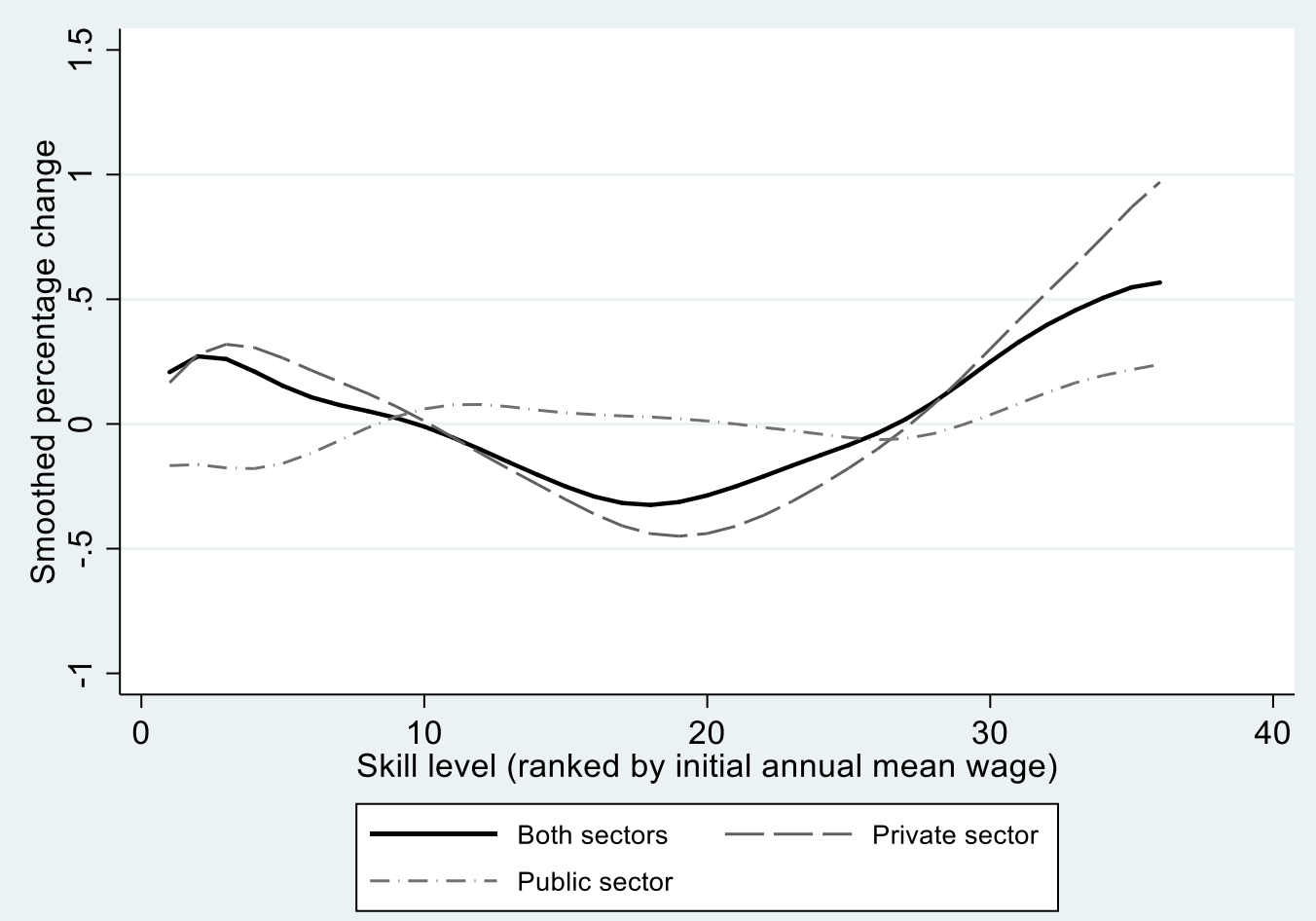

Notes: See Figure 1. 
Figure 3: Within and between firm components of total change in employment shares (in \%-points) by 1digit occupation group (between 2000 and 2014)

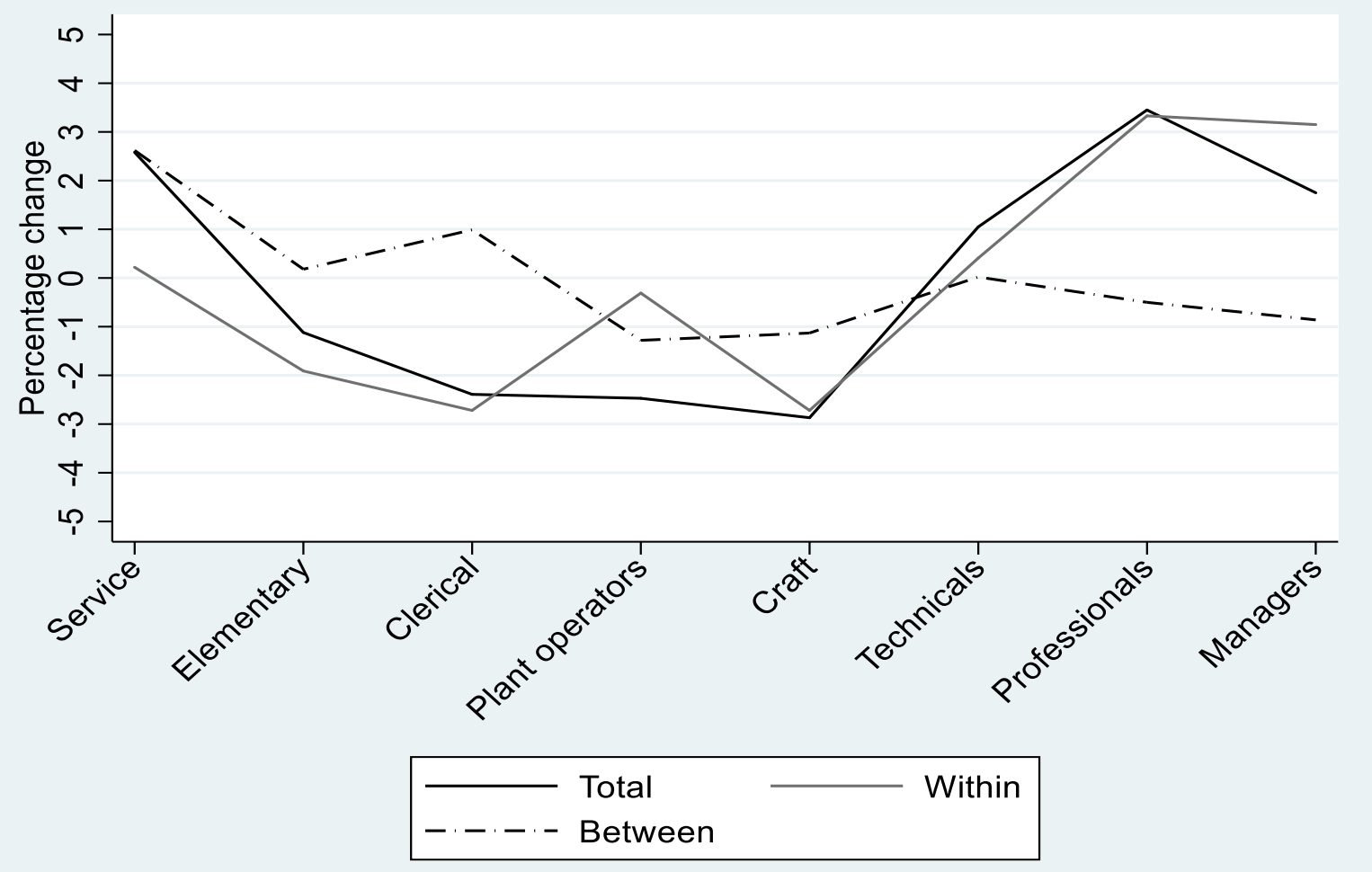

Notes: Includes all firms that had at least 1 employee in 2000 or 2014. Excludes public sector entities. 
Figure 4: Entry and exit components of total change in employment shares (in \%-points) by 1-digit occupation group (between 2000 and 2014)

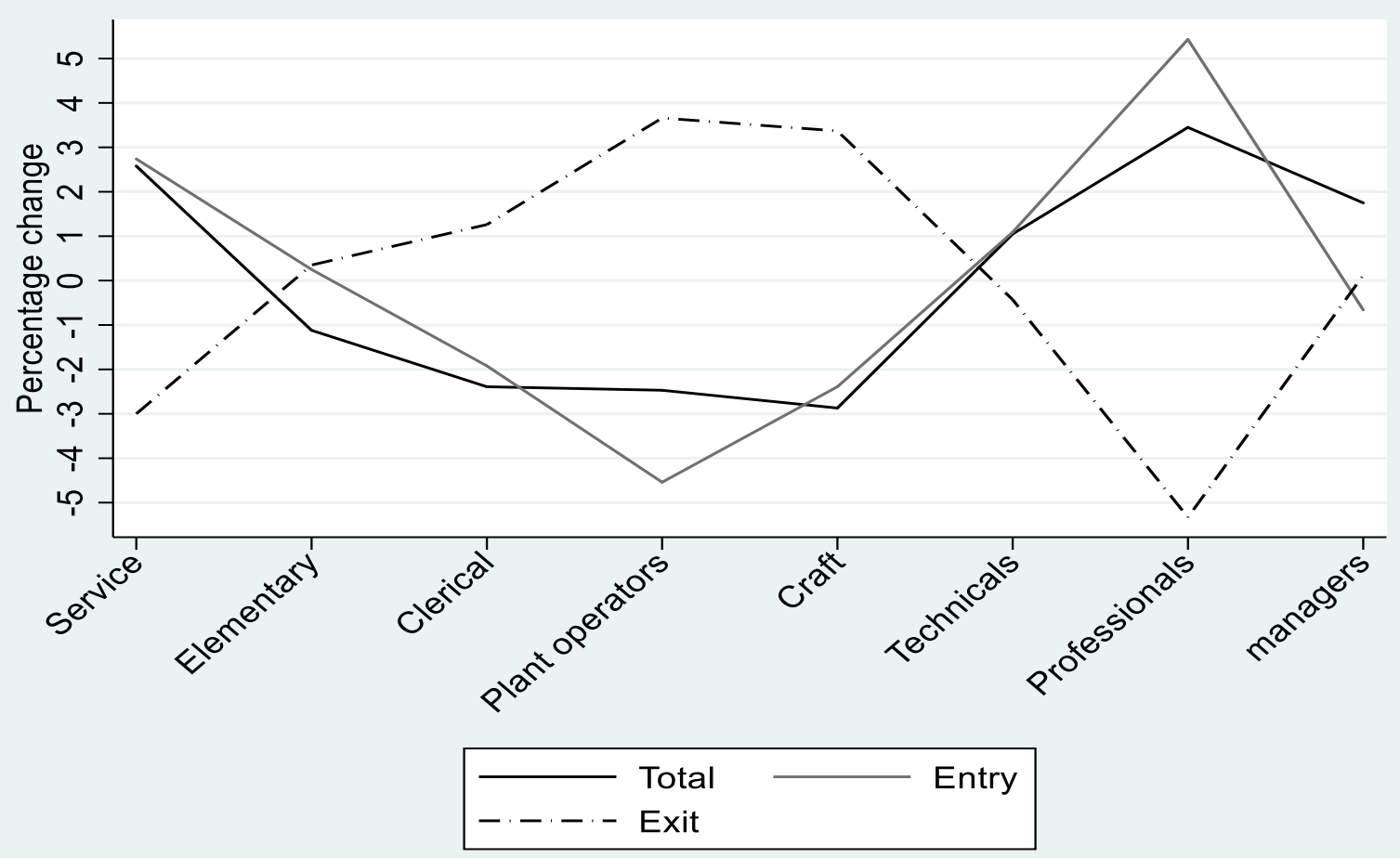

Notes: Includes all firms that had at least 1 employee in 2000 or 2014. Excludes public sector entities. 
Figure A1: The number of employees across 1-digit ISCO occupation categories, 2000, 2004-2014

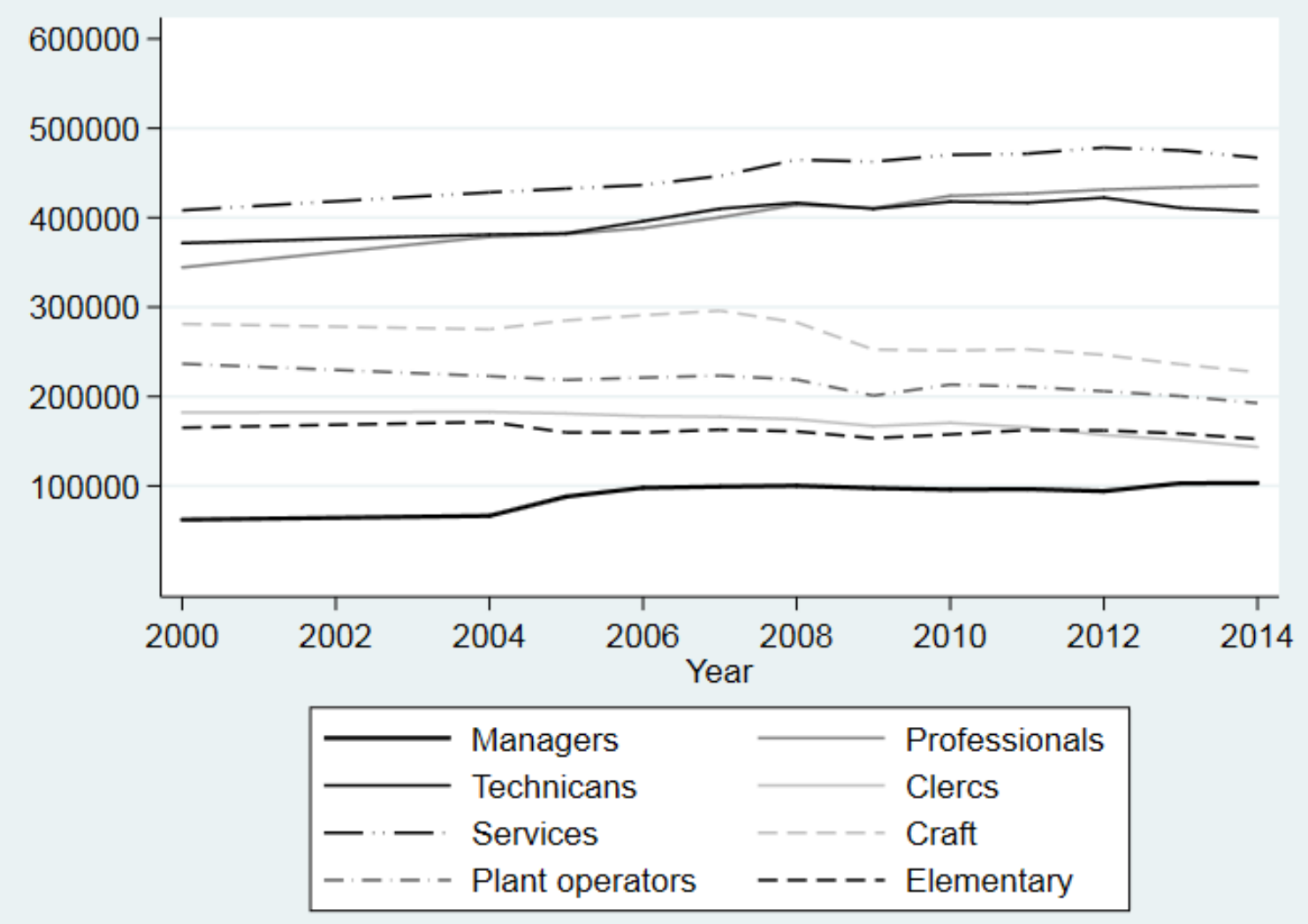


Figure A2: Smoothed change in annual wages by 2-digit occupation group (2000 and 2014)

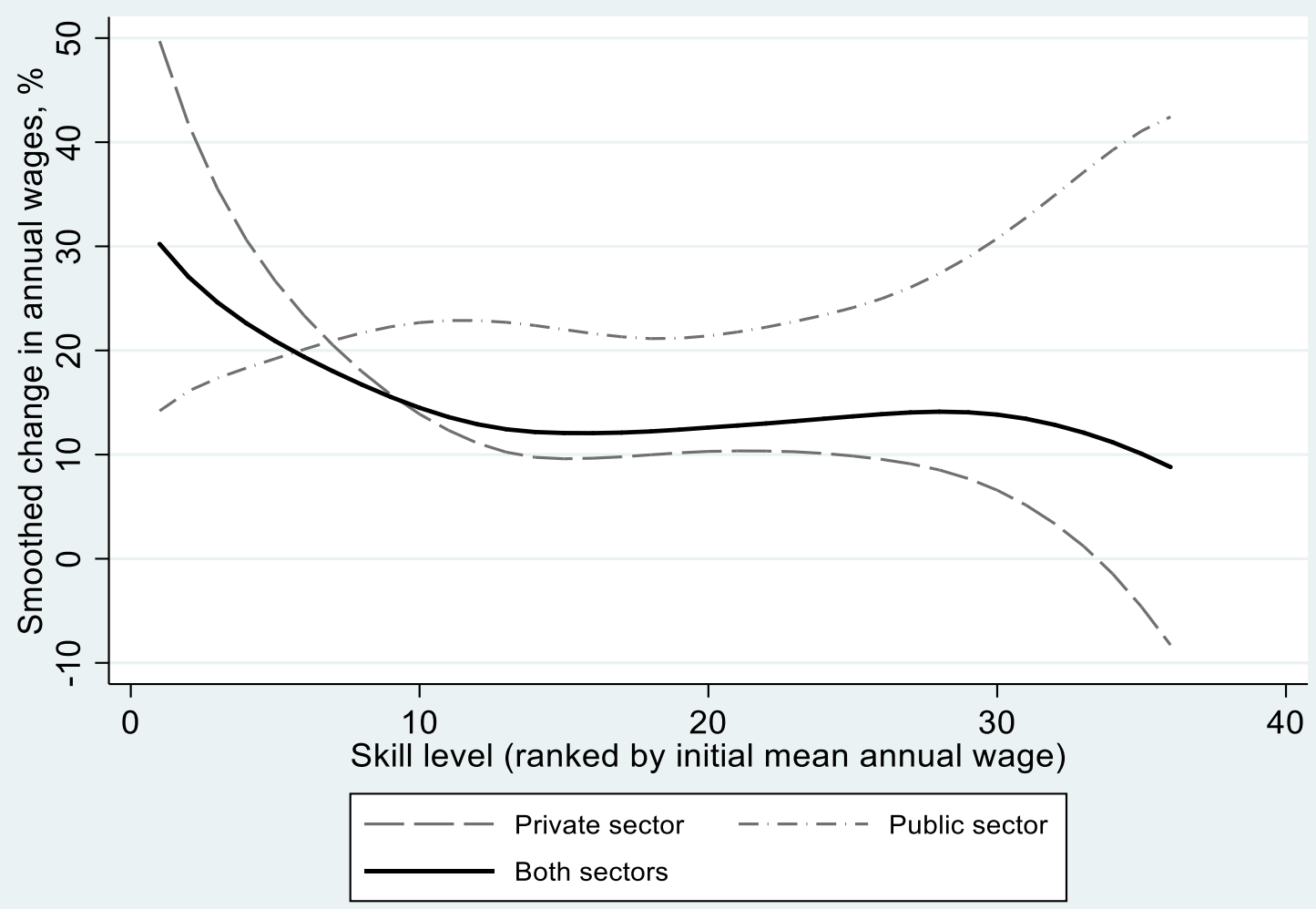

Notes: "Both sectors" includes all employees in the private and public sector, as well as self-employed individuals regardless of establishment size. Wages are deflated. Y-axis reflects percent the change from 2000 to 2014. 
Table A1: Descriptive statistics of the auxiliary data sets in continuing, entering and exiting firms

\begin{tabular}{|c|c|c|c|c|}
\hline & Year & $\begin{array}{r}\text { Continuing } \\
\text { firms }\end{array}$ & $\begin{array}{r}\text { Entering } \\
\text { Firms }\end{array}$ & $\begin{array}{r}\text { Exiting } \\
\text { firms }\end{array}$ \\
\hline \multirow[t]{2}{*}{ Exports of goods, $€$} & 2000 & 3.60 M. € & & 4.26 M. € \\
\hline & 2014 & 4.37 M. $€$ & $2.22 \mathrm{M} . €$ & \\
\hline \multirow[t]{2}{*}{ Import of goods, $€$} & 2000 & $2.42 \mathrm{M} . €$ & & 2.54 M. $€$ \\
\hline & 2014 & 3.85 M. $€$ & 2.86 M. $€$ & \\
\hline Number of firms & & 6,314 & 5,736 & 5,079 \\
\hline \multirow[t]{2}{*}{ Export of services, $€$} & 2000 & 0.92 M. $€$ & & $0.16 \mathrm{M} . €$ \\
\hline & 2014 & 0.94 M. $€$ & $1.25 \mathrm{M} . €$ & \\
\hline \multirow[t]{2}{*}{ Import of services, $€$} & 2000 & 0.65 M. $€$ & & 0.12 M. $€$ \\
\hline & 2014 & 0.93 M. $€$ & 0.96 M. $€$ & \\
\hline Number of firms & & 6,309 & 5,736 & 5,079 \\
\hline \multirow[t]{4}{*}{ R\&D expenditure/worker, $€$} & 2000 & $6,035 €$ & & $6,644 €$ \\
\hline & & {$[5,781 €]$} & & {$[6,564 €]$} \\
\hline & 2014 & $8,279 €$ & $10,959 €$ & \\
\hline & & {$[7,578 €]$} & {$[10,390 €]$} & \\
\hline \multirow[t]{2}{*}{ Number of firms } & & 1,111 & 862 & 906 \\
\hline & & {$[1,552]$} & {$[1,125]$} & {$[1,089]$} \\
\hline \multirow[t]{3}{*}{ Share of workers using ICT } & 2001 & $60 \%$ & & $63 \%$ \\
\hline & 2014 & $79 \%$ & $77 \%$ & \\
\hline & & {$[76 \%]$} & {$[70 \%]$} & \\
\hline \multirow[t]{2}{*}{ Number of firms } & & 484 & 778 & 762 \\
\hline & & {$[1,063]$} & {$[3,533]$} & \\
\hline \multirow[t]{2}{*}{ Share of firms outsourcing } & $2001-2006$ & $58 \%$ & & $51 \%$ \\
\hline & & & & {$[53 \%]$} \\
\hline \multirow[t]{2}{*}{ or planning to outsource } & $2001-2006$ & $58 \%$ & $54 \%$ & \\
\hline & & {$[53 \%]$} & {$[52 \%]$} & \\
\hline \multirow[t]{2}{*}{ Number of firms } & & 747 & 175 & 140 \\
\hline & & {$[1,356]$} & {$[268]$} & [257] \\
\hline
\end{tabular}

Note: Means and number of firms in brackets are calculated using survey weights (note that survey weights are not provided for the 2001 ICT survey). Outsourcing survey pertains to years 2001-2006. 
Table A2: Decomposition of change in employment share (\%-points) by occupation task group (2000 to 2014). Firm-level data.

\begin{tabular}{llllll}
\hline & Total change & Within & Between & Entry & Exit \\
Abstract & 5.1 & 7.2 & -1.0 & 0.8 & -1.9 \\
Routine cognitive & -0.5 & -1.4 & 1.5 & -2.9 & 2.3 \\
Routine manual & -6.9 & -3.4 & -2.4 & -8.6 & 7.6 \\
Non-routine manual & 2.3 & -2.4 & 1.9 & 10.7 & -7.9 \\
\hline
\end{tabular}

Note: Firms that had at least 10 employees during observation year 2000 and/or 2014 are included 
Table A3: Decomposition of change in employment share (\%-points) by occupation task group (2000 to 2014).

\begin{tabular}{|c|c|c|c|c|c|}
\hline $\begin{array}{l}\text { Panel A: } \\
\text { Firms that trade in goods }\end{array}$ & $\begin{array}{l}\text { Total } \\
\text { change }\end{array}$ & Within & Between & Entry & Exit \\
\hline Abstract & 9.6 & 8.0 & -0.5 & 2.3 & -0.2 \\
\hline Routine cognitive & -0.8 & -2.0 & 2.0 & -2.2 & 1.4 \\
\hline Routine manual & -17.6 & -3.7 & -2.8 & -8.6 & -2.5 \\
\hline Service & 8.8 & -2.3 & 1.3 & 8.5 & 1.3 \\
\hline $\begin{array}{l}\text { Panel B: } \\
\text { Outsourcing sample }\end{array}$ & $\begin{array}{l}\text { Total } \\
\text { change }\end{array}$ & Within & Between & Entry & Exit \\
\hline Abstract & 8.0 & 9.4 & -0.5 & -1.4 & 0.5 \\
\hline Routine cognitive & 0.6 & -2.6 & 0.8 & 1.6 & 0.8 \\
\hline Routine manual & -9.3 & -3.6 & -2.4 & -1.5 & -1.8 \\
\hline Service & 0.7 & -3.2 & 2.1 & 1.3 & 0.5 \\
\hline $\begin{array}{l}\text { Panel C: } \\
\text { ICT sample }\end{array}$ & $\begin{array}{l}\text { Total } \\
\text { change }\end{array}$ & Within & Between & Entry & Exit \\
\hline Abstract & 6.8 & 6.8 & 0.2 & -0.1 & -0.1 \\
\hline Routine cognitive & 2.0 & -1.2 & 3.5 & -0.2 & -0.1 \\
\hline Routine manual & -6.7 & -3.2 & -3.4 & -0.1 & 0.0 \\
\hline Service & -2.1 & -2.4 & -0.3 & 0.4 & 0.2 \\
\hline $\begin{array}{l}\text { Panel D: } \\
\text { R\&D sample }\end{array}$ & $\begin{array}{l}\text { Total } \\
\text { change }\end{array}$ & Within & Between & Entry & Exit \\
\hline Abstract & 7.6 & 9.0 & -0.4 & -0.2 & -0.8 \\
\hline Routine cognitive & 1.7 & -3.6 & 2.1 & -0.3 & 3.5 \\
\hline Routine manual & -13.2 & -3.8 & -3.8 & -2.2 & -3.3 \\
\hline Service & 3.8 & -1.6 & 2.1 & 2.7 & 0.6 \\
\hline $\begin{array}{l}\text { Panel E: } \\
\text { Trade of services sample }\end{array}$ & $\begin{array}{l}\text { Total } \\
\text { change }\end{array}$ & Within & Between & Entry & Exit \\
\hline Abstract & 9.5 & 9.2 & 1.1 & 0.4 & -1.2 \\
\hline Routine cognitive & 0.9 & -2.7 & 0.4 & 0.6 & 2.6 \\
\hline Routine manual & -15.1 & -4.0 & -3.0 & -5.4 & -2.7 \\
\hline Service & 4.7 & -2.5 & 1.5 & 4.4 & 1.3 \\
\hline
\end{tabular}

Note: Firms that had at least 10 employees during year 2000 and/or 2014 are included.

Employees with zero earnings and less than six employment months are excluded. Panel A includes $(\mathrm{N}=10,444)$ firms that had a positive amount of imported or exported goods in 2000 and 2014. Panel B includes $(\mathrm{N}=1,304)$ firms that responded the International Sourcing Survey. Panel C includes $(\mathrm{N}=532)$ firms that responded the ICT survey both in 2000 and 2014. Panel D includes $(N=4,999)$ firms that responded the $R \& D$ survey both in 2000 and 2014. Panel E includes $(N=2,776)$ firms that had a positive amount of imported or exported services in 2000 and 2014. 
Table A4: Reduced form estimates: global export and import shocks

\begin{tabular}{llllc}
\hline Explanatory variable & Abstract & Routine cognitive & Routine manual & Services \\
\cline { 2 - 5 } World export demand & $-0.0130 * * *$ & $-0.0110 * * *$ & $0.0242 * * *$ & -0.0003 \\
& $(0.0019)$ & $(0.0016)$ & $(0.0017)$ & $(0.0011)$ \\
World import demand & $-0.0096 * * *$ & $0.0033^{*}$ & 0.0018 & $0.0045 * * *$ \\
& $(0.0020)$ & $(0.0017)$ & $(0.0018)$ & $(0.0012)$ \\
Number of firms & 6,314 & 6,314 & 6,314 & 6,314 \\
\hline
\end{tabular}

Notes: The total number of employees in the firm in 2000 is used to weight the observations. *** $(\mathrm{p}<0.01), * *(\mathrm{p}<0.05)$ and $*(\mathrm{p}<0.10)$. Standard errors in parentheses. Other controls: average age of employees, average wage of employees and industry dummies in 2000. 
Table A5: Firm-level 2SLS regressions for change in occupation share between 2000 and 2014 by industry. International trade of goods.

\begin{tabular}{|c|c|c|c|c|c|}
\hline \multirow{2}{*}{$\begin{array}{l}\text { Explanatory variable } \\
\text { Panel A: Manufacturing } \\
\text { Change in export of goods, } \\
\text { 2SLS }\end{array}$} & Abstract & $\begin{array}{l}\text { Routine } \\
\text { cognitive }\end{array}$ & $\begin{array}{l}\text { Routine } \\
\text { manual }\end{array}$ & Service & $\begin{array}{l}\text { Polarization } \\
\text { index }\end{array}$ \\
\hline & $\begin{array}{l}-0.0124 * * * \\
(0.0047)\end{array}$ & $\begin{array}{l}-0.0072 * * \\
(0.0030)\end{array}$ & $\begin{array}{l}0.0178 * * * \\
(0.0054)\end{array}$ & $\begin{array}{l}0.0017 * \\
(0.0010)\end{array}$ & $\begin{array}{l}-0.0066 \\
(0.0057)\end{array}$ \\
\hline \multirow[t]{2}{*}{$\begin{array}{l}\text { Change in import of goods, } \\
\text { 2SLS }\end{array}$} & $-0.0097 * *$ & -0.0006 & $0.0118 * *$ & -0.0016 & $-0.0150 * * *$ \\
\hline & $(0.0045)$ & $(0.0029)$ & $(0.0052)$ & $(0.0010)$ & $(0.0054)$ \\
\hline $\begin{array}{l}\text { 1st stage, export: } \\
\text { 1st stage, import: }\end{array}$ & \multicolumn{5}{|c|}{$\begin{array}{l}\text { iv_exp: } 0.849 * * *(0.071) \text {, iv_imp: } 1.012 * * *(0.112), \text { C-D F-test: } 27.62 \\
\text { iv_exp: } 1.146 * * *(0.064) \text {, iv_imp: } 0.319 * * *(0.100)\end{array}$} \\
\hline Number of firms & 1,612 & 1,612 & 1,612 & 1,612 & 1,612 \\
\hline \multirow{2}{*}{$\begin{array}{l}\text { Panel B: Construction } \\
\text { Change in export of goods, } \\
\text { 2SLS } \\
\text { Change in import of goods, } \\
\text { 2SLS }\end{array}$} & $\begin{array}{l}0.0263 * * * \\
(0.0053)\end{array}$ & $\begin{array}{l}0.0297 * * * \\
(0.0062)\end{array}$ & $\begin{array}{l}-0.0562 * * * \\
(0.0107)\end{array}$ & $\begin{array}{l}0.0001 \\
(0.0011)\end{array}$ & $\begin{array}{l}0.0303 * * * \\
(0.0067)\end{array}$ \\
\hline & $\begin{array}{l}0.0009 \\
(0.0045)\end{array}$ & $\begin{array}{l}0.0056 \\
(0.0053)\end{array}$ & $\begin{array}{l}-0.0082 \\
(0.0091)\end{array}$ & $\begin{array}{l}0.0017 * \\
(0.0009)\end{array}$ & $\begin{array}{l}0.0051 \\
(0.0057)\end{array}$ \\
\hline $\begin{array}{l}\text { 1st stage, export: } \\
\text { 1st stage, import: }\end{array}$ & \multicolumn{5}{|c|}{$\begin{array}{l}\text { iv_exp: }-1.734 * * *(0.309) \text {, iv_imp: } 1.354 * * *(0.175), \text { C-D F-test: } 10.03 \\
\text { iv_exp: } 3.188 * * *(0.292) \text {, iv_imp: }-0.455 * * *(0.166)\end{array}$} \\
\hline Number of firms & 593 & 593 & 593 & 593 & 593 \\
\hline $\begin{array}{l}\text { Panel C: Services } \\
\text { Change in export of goods, } \\
\text { 2SLS }\end{array}$ & $\begin{array}{l}-0.0341 * * * \\
(0.0080)\end{array}$ & $\begin{array}{l}0.0251 * * * \\
(0.0079)\end{array}$ & $\begin{array}{l}-0.0048 \\
(0.0042)\end{array}$ & $\begin{array}{l}0.0138 * * * \\
(0.0046)\end{array}$ & $\begin{array}{l}-0.0103 \\
(0.0095)\end{array}$ \\
\hline $\begin{array}{l}\text { Change in import of goods, } \\
\text { 2SLS }\end{array}$ & $\begin{array}{l}-0.0216 * * * \\
(0.0068)\end{array}$ & $\begin{array}{l}-0.0271 * * * \\
(0.0067)\end{array}$ & $\begin{array}{l}0.0126 * * * \\
(0.0036)\end{array}$ & $\begin{array}{l}-0.0071 \\
(0.0040)\end{array}$ & $\begin{array}{l}0.0107 \\
(0.0082)\end{array}$ \\
\hline $\begin{array}{l}\text { 1st stage, export: } \\
\text { 1st stage, import: }\end{array}$ & \multicolumn{5}{|c|}{$\begin{array}{l}\text { iv_exp: } 0.640 * * *(0.074) \text {, iv_imp: } 0.766 * * *(0.058), \text { C-D F-test: } 21.54 \\
\text { iv_exp: } 1.257 * * *(0.096), \text { iv_imp: } 0.454 * * *(0.076)\end{array}$} \\
\hline Number of firms & 2,926 & 2,926 & 2,926 & 2,926 & 2,926 \\
\hline
\end{tabular}

Notes: The total number of employees in the firm in 2000 is used to weight the observations. $* * *(p<0.01)$, $* *(\mathrm{p}<0.05)$ and $*(\mathrm{p}<0.10)$. Standard errors in parentheses. Other controls: average age of employees and average wage of employees.

Table A6: Firm-level OLS and 2SLS regressions for change in occupation share between 2000 and 2014. International trade of goods. 


\section{Explanatory variable}

\section{Panel A: OLS regression}

Change in export of goods

Change in import of goods

Panel B: IV regression

Change in export of goods, 2SLS $-0.0063 *$

Change in import of goods, 2SLS

$1^{\text {st }}$ stage, export: $1^{\text {st }}$ stage, import:
56.33
(0.0038)

\section{Clerical}

and

technicals

$-0.0112 * * *$

$-0.0001$

$(0.0004)$

$-0.0127 * * *$

$(0.0005)$

$0.0019 * * *$

$(0.0003)$

$0.0123 * * *$

$(0.0027)$

$-0.0111 * * *$

\section{Craft and Service and plant operators elementary workers}

$$
(0.0024) \quad(0.0047)
$$

$0.0015 * * *$

$(0.0004)$

$0.0063 * * *$

(0.0004)

iv_exp: $0.769 * * *(0.043)$, iv_imp: $0.834 * * *(0.046)$, C-B F-test:

iv_exp: $1.207 * * *(0.048)$, iv_imp: $0.393 * * *(0.052)$,

Number of firms

6,491

6,491

6,491

6,491

Notes: The total number of employees in the firm in 2000 is used to weight the observations. *** $(p<0.01), * *(p<0.05)$ and $*(p<0.10)$. Standard errors in parentheses. Other controls: average age of employees, average wage of employees and industry dummies in 2000. 
Table A7: Firm-level OLS and 2SLS regressions for change in occupation share between 2000 and 2014. Outsourcing.

\begin{tabular}{|c|c|c|c|c|}
\hline Explanatory variable & $\begin{array}{l}\text { Managers, } \\
\text { professionals } \\
\text { and technicals }\end{array}$ & Clerical & $\begin{array}{l}\text { Craft and } \\
\text { plant } \\
\text { operators }\end{array}$ & $\begin{array}{l}\text { Service and } \\
\text { elementary } \\
\text { workers }\end{array}$ \\
\hline \multicolumn{5}{|l|}{ Panel A: Outsourcing, OLS } \\
\hline Outsourcing/Offshoring & $\begin{array}{l}0.0668 * * * \\
(0.0195)\end{array}$ & $\begin{array}{l}-0.0125 \\
(0.0113)\end{array}$ & $\begin{array}{l}-0.0416 * * * \\
(0.0157)\end{array}$ & $\begin{array}{l}-0.0127 \\
(0.0132)\end{array}$ \\
\hline \multicolumn{5}{|l|}{$\begin{array}{l}\text { Panel B: Outsourcing in } \\
\text { Finland, Abroad versus } \\
\text { planned, OLS }\end{array}$} \\
\hline Outsourcing in Finland & $\begin{array}{l}0.0099 \\
(0.0182)\end{array}$ & $\begin{array}{l}-0.0147 \\
(0.0104)\end{array}$ & $\begin{array}{l}0.0192 \\
(0.0146)\end{array}$ & $\begin{array}{l}-0.0144 \\
(0.0122)\end{array}$ \\
\hline Outsourcing abroad & $\begin{array}{l}0.0228 \\
(0.0204)\end{array}$ & $\begin{array}{l}0.0218 * \\
(0.0117)\end{array}$ & $\begin{array}{l}-0.0845 * * * \\
(0.0161)\end{array}$ & $\begin{array}{l}0.0400 * * * \\
(0.0137)\end{array}$ \\
\hline Plan to outsource 2007- & $\begin{array}{l}0.0375 \\
(0.0278)\end{array}$ & $\begin{array}{l}0.0577 * * * \\
(0.0158)\end{array}$ & $\begin{array}{l}-0.0388 * \\
(0.0223)\end{array}$ & $\begin{array}{l}-0.0564 * * * \\
(0.0186)\end{array}$ \\
\hline \multicolumn{5}{|l|}{ Panel C: Outsourcing, IV } \\
\hline Outsourcing / offshoring, 2SLS & $\begin{array}{l}-0.2162 * * \\
(0.1072)\end{array}$ & $\begin{array}{l}-0.0993 * \\
(0.0776)\end{array}$ & $\begin{array}{l}-0.0903 \\
(0.0766)\end{array}$ & $\begin{array}{l}0.4059 * * * \\
(0.0983)\end{array}$ \\
\hline $1^{\text {st }}$ stage & \multicolumn{4}{|c|}{ iv_exp: $0.177 * * *(0.031)$, iv_imp: $0.004(0.027)$, F-test: 16.16} \\
\hline \multicolumn{5}{|c|}{ Panel D: Outsourcing in Finland, abroad versus planned, IV } \\
\hline Outsourcing in Finland, 2SLS & $\begin{array}{l}-0.2743 * * \\
(0.1185)\end{array}$ & $\begin{array}{l}-0.1241 * * \\
(0.0631)\end{array}$ & $\begin{array}{l}-0.0112 \\
(0.0827)\end{array}$ & $\begin{array}{l}0.4095 * * * \\
(0.1120)\end{array}$ \\
\hline $1^{\text {st }}$ stage & \multicolumn{4}{|c|}{ iv_exp: 0.160 (0.034), iv_imp: -0.028 (0.029), F-test: 11.74} \\
\hline Outsourcing abroad, 2SLS & $\begin{array}{l}0.2668 \\
(0.1767)\end{array}$ & $\begin{array}{l}0.1092 \\
(0.0961)\end{array}$ & $\begin{array}{l}-0.5950 * * * \\
(0.1959)\end{array}$ & $\begin{array}{l}0.2189 * \\
(0.1200)\end{array}$ \\
\hline $1^{\text {st }}$ stage & \multicolumn{4}{|c|}{ iv_exp: $0.013(0.030)$, iv_imp: $0.089 * * *(0.026)$, F-test: 5.90} \\
\hline Plan to outsource 2007- , 2SLS & $\begin{array}{l}-1.0188 \\
(0.6298)\end{array}$ & $\begin{array}{l}-0.4401 \\
(0.3190)\end{array}$ & $\begin{array}{l}1.0498 * \\
(0.6041)\end{array}$ & $\begin{array}{c}0.4091 \\
(0.3330)\end{array}$ \\
\hline $1^{\text {st }}$ stage & \multicolumn{4}{|c|}{ iv_exp: $0.020(0.022)$, iv_imp: $-0.035 *(0.019)$, F-test: 2.11} \\
\hline Number of firms & 748 & 748 & 748 & 748 \\
\hline
\end{tabular}

Notes: The total number of employees in the firm in 2000 is used to weight the observations. *** $(p<0.01),{ }^{* *}(p<0.05)$ and $*(p<0.10)$. Standard errors in parentheses. Other controls: average age of employees, average wage of employees and industry dummies in 2000. 